Article

\title{
Sustainable Entrepreneurial Process: From Idea Generation to Impact Measurement
}

\author{
Daniele Eckert Matzembacher ${ }^{1, * \mathbb{D}}$, Mervi Raudsaar ${ }^{2}$, Marcia Dutra de Barcellos ${ }^{1}$ and \\ Tõnis Mets ${ }^{2}$ (D) \\ 1 School of Business Administration, Federal University of Rio Grande do Sul, 90010-460 Porto Alegre, Brazil; \\ marcia.barcellos@ufrgs.br \\ 2 School of Economics and Business Administration, University of Tartu, 50407 Tartu, Estonia; \\ mervi.raudsaar@ut.ee (M.R.); tonis.mets@ut.ee (T.M.) \\ * Correspondence: daniele.eckert@ufrgs.br
}

Received: 4 October 2019; Accepted: 21 October 2019; Published: 23 October 2019

\begin{abstract}
In order to promote sustainable entrepreneurship, it is necessary to understand the sustainable entrepreneurial process. To address this gap in the literature, this study aims to investigate how entrepreneurs generate ideas, as well as recognize, develop, and exploit opportunities in the context of sustainable development. A case study was carried out with eleven organizations in six different countries, from different sectors, including not-for-profit and for-profit businesses. The findings address a series of mechanisms that occur prior to the process of generating an idea and are relevant to the positive impact of these businesses on society. Entrepreneurs' previous experiences and skills, as well as the knowledge of similar initiatives, strongly relate to motivation and idea generation. In the analyzed cases, prior experience seemed to be related to a sensitivity towards a social or environmental problem. Previous experience in entrepreneurship was not determinant. The quality of the initial idea was relevant, once little changes occurred throughout the entire process. In most situations both dimensions of sustainability were integrated at the same time and before venture launch. Despite this, the focus of the entrepreneurs was on only one dimension. The inclusion of positive impact measurement on society, as part of the sustainable entrepreneurial process model, is another relevant finding. First, it is necessary to differentiate the sustainable entrepreneur from the regular and the social entrepreneur. Secondly, in some situations, the dimensions of sustainability are not integrated at the same time and before venture launch, and therefore considering that the process is finished in the phase of venture launch can lead to misclassifications. The results also led to the recognition of triggers that can stimulate sustainable entrepreneurship, such as educational practices more aligned with sustainability problems faced by local communities, stronger dissemination of successful business cases related to sustainability in other countries and contexts, integration between universities and businesses, and the inclusion of practice-based learning in curricula. A contribution to the literature was achieved by providing a systemic perspective on sustainable entrepreneurial process. This study also contributes by presenting empirical evidence of the phenomenon of sustainable entrepreneurship. The holistic knowledge of this process provides new information that supports academics, policy makers, government, and individuals with a more appropriate understanding of the conditions that help to stimulate new business activities dealing with economic, social, and environmental problems faced in society, helping to achieve the United Nations Sustainable Development Goals.
\end{abstract}

Keywords: sustainable entrepreneurship; entrepreneurial process; sustainable development 


\section{Introduction}

Humanity is experiencing unprecedented complexities related to production and consumption systems, each with its own ecological, economical, and social dimensions without a single cause or a simple solution [1]. Sustainable entrepreneurship is expected to help mitigate some of these challenges, reconciling disparities in wealth, economic and social inclusion, educational access, and environmental issues [2-4].

Social or sustainable entrepreneurship is an umbrella term for a variety of organizational innovations that target social and environmental challenges [5]. Sustainable entrepreneurship is different from social entrepreneurship. A business must address the social and economic dimensions of sustainability to be considered a social entrepreneurship [6]. A necessary requirement of sustainable entrepreneurship is to address, at the same time, economic, social, and ecological goals, i.e., the triple bottom line approach [7]. A common point is that both are able to solve problems not addressed by either the regular market or the public sector [8,9]. These ventures are increasingly lauded as catalysts for change in society by researchers, policymakers, practitioners, and the media [10-13].

Nevertheless, although the contributions to society of successful sustainable entrepreneurship are of great importance, the empirical phenomenon itself is still rare [13]. A key challenge for researchers and practitioners is to understand and promote such practices [2]. In order to disseminate and promote sustainable entrepreneurship, it is necessary to understand the sustainable entrepreneurial process (SEP). Many authors describe the logic of the regular entrepreneurial process. Mainly, it includes the following sub-process or actions: idea generation, opportunity recognition, opportunity development, and venture launch [14]. Prior research in this area, generally, has characterized new venture creation as a process of opportunity identification, evaluation, and exploitation [15], and as fundamental to create value for individuals and societies [8,16]. Creating social value is about social impact [17]. The creation of positive economic, social, or environmental impact on society is considered a necessary condition for a social or sustainable entrepreneurship $[3,4,7,8,11,12,18]$.

In this sense, despite contemporary practices of sustainable entrepreneurship having many similarities with regular business, significant differences still exist [19], leading researchers to question whether sustainable entrepreneurships require specific theories or not [20]. There is a need to empirically investigate this phenomenon beyond the venture development [3]. Recent publications indicate a need for further investigation on the most diverse stages of the regular, social, and mainly SEP and business exploitation. First, there is a gap regarding whether and how SEP might unfold [6,21]. Second, there is a gap in the literature regarding the emergence of venture ideas [12], the origin of entrepreneurial opportunities [15,22], and the influence of prior experience on the idea generation [16]. Third, the motivation of the entrepreneur also needs more attention [18], mainly related to its impact on opportunity recognition [9]. In fact, opportunity recognition is considered an essential part of SEP, but studies that address this phenomenon are rare $[21,22]$. A refined view of the process may help educators develop courses that focus on triggers as starting points for students to engage in idea generation [16].

Moreover, little is known about SEP regarding business model designs [12], the early stages of business development [13], funding issues, and different legal forms [18]. An understanding of the processes and mechanisms of social ventures and how they exactly catalyze social change, through the entrepreneurial process, is also underdeveloped $[10,18]$. Finally, after an extensive search in the literature, the paper by Belz and Binder [6] best summarizes the current development of the research explored in this paper. They found only six empirical studies that investigated the recognition, development, or exploitation of opportunities in social and environmental contexts. Among these papers, only one, (Perrini et al. [23]), explored the entire entrepreneurial process, however, they analyzed only one single case study in a not-for-profit organization. Starting from this gap, Belz and Binder [6] investigated the SEP in four for-profit companies and identified a SEP model that incorporated social and environmental dimensions in separate moments, however, they recognized that further studies are necessary to better understanding this phenomenon. Moreover, according to Filser et al. [24], current knowledge about how entrepreneurial activities contribute to the achievement of the United Nations Sustainable Development Goals is still limited and should be addressed by 
researchers. Understanding the SEP, in addition to contributing to the theoretical advancement of the gaps abovementioned, has the potential of generating knowledge to help academics, police makers, entrepreneurs, and individuals identify how to promote win-win solutions through business, generating economic growth with benefits that contribute to the achievement of the United Nations Sustainable Development Goals.

The question that emerges from this is how do entrepreneurs generate ideas, as well as recognize, develop, and exploit opportunities in the context of sustainable development? It is expected to contribute theoretically in responding to the gaps pointed out in the literature, by offering a more holistic and integrated view of the SEP processes and business exploitation.

One premise of this study is that gaps in the literature related to regular and social entrepreneurship extend to SEP. Therefore, part of the literature used is also embedded in references of these groups. The rest of this paper is structured as follows: The second section explores the difference between concepts of regular, social, and sustainable entrepreneurship, and reviews the theoretical background on SEP; the third section explains the methodology and presents the cases under study; the fourth section presents the findings from the investigation; the fifth part discusses the findings; and, finally, the sixth concludes with implications in theory and practice.

\section{Theoretical Background}

Several authors propose a sub-process to analyze the entrepreneurial process of regular enterprises (for example, [16,25]). In relation to social entrepreneurship, two authors stand out. First, Perrini et al. [23] proposed a five-phase model, including opportunity identification, evaluation, formalization, exploitation, and opportunity scaling up (related to replication for social change maximization). Mets, Raudsaar and Summatavet [14] proposed a four-phase model, idea generation, opportunity recognition, opportunity development, and venture launch. Venture launch could also be understood as opportunity exploitation. Each phase of the entrepreneurial process is the result of a combination of physical and mental shapes, which are grouped into silos related to each stage, propositions, idea development, concept development, and business development. The content of a silo is not static, since there is a reciprocal interaction between its components, as well as an interaction with the main SEP. In relation to SEP, Belz and Binder [6] proposed a six-stage process which included recognizing a social or ecological problem, recognizing a social or ecological opportunity, developing a double bottom line solution, developing a triple bottom line solution, funding and forming a sustainable enterprise, and creating or entering a sustainable market.

The model proposed by Mets, Raudsaar, and Summatavet [14] was chosen to provide suitable analysis categories for this investigation for three main reasons. Although it applies to the context of social entrepreneurship, the model was tested in both not-for-profit and for-profit sectors. In addition, the model is structured on the idea of silos, facilitating the analytical coding, as compared with the abovementioned models. Finally, the research through this model identifies if the results found by Belz and Binder [6] occur empirically in the context of SEP by incorporating triple bottom line integration questions, in the cases analyzed, in addition to having several elements in common during the other phases.

\subsection{Idea Generation}

Idea generation is the result of several propositions, which relates mainly to motivation, prior knowledge, and the skills or capabilities of the entrepreneur [14]. Recent research indicates that the quality of the original conception of an idea (raw idea) is a key determinant of the entrepreneurial success [26]. If it makes a difference for future performance, this would imply that it is important to understand how this process occurs in detail [16].

Sustainability-oriented entrepreneurial intentions are driven by perceived entrepreneurial desirability and attitude toward sustainability [27]. Perrini et al. [23] identified that sensitivity towards a social problem fosters idea generation. In this sense, an idea can be related to prior history of 
an individual [28], i.e., prior knowledge and experience, such as education, work experience, hobbies, and family background $[4,19,21,29-31]$. A potential starting point is the recognition of a social or ecological problem, which the prospective entrepreneurs encountered and experienced in their private or professional lives [6].

Yitshaki and Kropp [9] analyzed 30 social entrepreneurs and identified pull factors, which included prosocial behaviors based on past or current life events, that motivated the majority of the participants and happened through social awareness since childhood or early adulthood. Their experiences created an awareness of unmet societal needs, which led to opportunity recognition and the formation of social ventures to help fill the gaps. Others were motivated by push factors related to identification of social needs or the process of evolution of an idea as a natural option for career development, for example, searching for a meaningful career due to job dissatisfaction or unemployment [9].

Although some prospective entrepreneurs desire to be self-employed, according to an individual's personal circumstances [21], compared to their business for-profit counterparts, sustainable entrepreneurs have significant differences in their motivations. In social entrepreneurship, a smaller number of people tend to respond that the motivation "to become your own boss and be independent" and "to create personal financial security" are influencing factors, unlike business entrepreneurs who have been characterized as motivated by an elevated need for achievement and autonomy [19]. In a study conducted with creative entrepreneurs, Karhunen et al. [30] also identified that almost all of them fit into the category of pull factors.

In fact, as well as commercial entrepreneurs, goal setting drives idea generation among social entrepreneurs [9], however, it seems that the social entrepreneurship arena is most often connected to solving a problem as an antecedent that leads to opportunity recognition. Social entrepreneurs tend to consider opportunities that have enough potential for positive social influences more attractive $[9,19]$. It involves a process of solving a tension between an unmet social need that is linked to a broad social mission in favor of the community rather than a gap between needs and demands [9]. Their motivation combines sustainability-oriented goals with a profit goal [32]. Sustainable entrepreneurs are engrossed in, and motivationally displaced by, other human and nonhuman stakeholders, causes, and ventures in different dynamic relations [2]. Therefore, as proposes by Yitshaki and Kropp [9], motivations of sustainable entrepreneurs are mission driven and designed to improve the well-being of a specific group or society.

\subsection{Opportunity Recognition}

Opportunity recognition is the output of the idea development. This silo relates to social assets, goals, and social needs [14]. Identifying and shaping opportunity is central to the domain of entrepreneurship [8]. Similar to the previous stage, the recognition of sustainable opportunities is affected by prior knowledge [21,22,30,31] and communal context; motivation for personal gain, such as earn money; and motivation to develop gains for others, i.e., altruism. The entrepreneurs' knowledge moderates it. Actions such as socialization can enhance entrepreneurs' knowledge of natural and communal environments, since personal situations and circumstances also contribute to their process of opportunity recognition, as well as family background, engagement in sustainability movements, and the media can help achieve it [21]. It can also involve extensive reading, conversations with others who work in the field, traveling to new places, attendance at professional meetings and workshops, and a general absorption of information [30].

The recognition of a solution to a problem is expected to also offer an opportunity in the market. Market imperfections are expected to contribute to ecological and social problems, which are perceived as opportunities by prospective sustainable entrepreneurs [6]. Therefore, the next critical question, after formulating the initial business idea, is whether there would be a market for the product or service. This includes both customer demand and the competitive advantage of the enterprise vis-a-vis competitors [30]. 
Testing the idea before starting the business occurs during this stage $[9,30]$, since this idea must meet consumers' needs [33]. Therefore, plausible evaluation of the social needs and assets related to opportunity recognition are necessary. Socialization, the participation in fairs, or launching a beta-version can help achieving this [14].

In this sense, opportunity recognition is a favorable combination of endogenously shaped and exogenously given circumstances that make it both desirable and feasible for the entrepreneur to exploit a venture concept and to introduce a potentially value-adding offer into the marketplace [16,22]. Therefore, once an idea is generated, the entrepreneur must take further actions to understand whether there is an opportunity or not to launch a successful venture based on the idea $[8,16]$.

\subsection{Opportunity Development}

As a solution to a particular social or ecological problem becomes feasible, and as market needs become more precise in terms of value sought by selected customer groups, the initial idea progresses, and a business concept emerges [6]. Opportunity development is the outcome of several activities related to the business concept development, such as marketing mix, business model, and available resources [14]. The business plan is one of the important activities launched [30] by successful ventures to achieve financial sustainability and to produce a desirable social impact [12]. The entrepreneurs that are more structured in their progress from transforming the identified opportunity into a business concept usually formulate a detailed business plan, which includes a business model, desired values, and deployed resources [6].

During the incubation stage, the entrepreneur collects missing information and constructs a more refined image of what the future company might look like [16]. The time that the team invests in the development of a nascent venture is vital. Expanding the hours spent on the venture increases the likelihood of organizational emergence [13]. A crucial element is the translation of a social or ecological goal into customer benefits. In this sense, the integration of the triple bottom line is a complex process, which takes place sequentially, not simultaneously. All three dimensions of economic, social, and ecological goals are considered and, at least, they are partly integrated before market entry, which adds credibility to the new venture and its sustainable offering [6].

\subsection{Venture Launch and Business Exploitation}

At some point, the individual will evaluate whether or not it is worthwhile to move to exploitation [16]. Business development first relates to preparing the venture to be launched. It involves developing a strategy and acquiring any missing tangible and intangible resources, such as teambuilding. It also relates to legal requirements. The outcome is the venture launch that could also be understood as opportunity exploitation [14]. It is the moment when the sustainable product or service is commercialized in the market [6].

Finding financing and other support for the entrepreneurial activity are the next general challenges of the beginning activities. The sources of financing to start and proceed with entrepreneurship can be internal and external. The former refers to the entrepreneur's own resources, such as personal savings and, after, financing created by the entrepreneurial activity (cash flow). The latter includes both public and commercial sources, including start-up subsidies and loans from business support structures, banks, and other commercial financial institutions [30], as well as crowd funding and public funding [6]. Social entrepreneurs can use other types of support (not financial) during the start-up phase. Shaw and Carter [19] investigated the level of personal financial risk experienced by founding social entrepreneurs. They discovered that while personal and family sources have been identified as key contributors to financing business enterprises, for the participating social entrepreneurs these sources were rarely used. Only a few respondents had made use of their own funds. A significant number of respondents identified charitable trusts, regional and central government, and European Union funding as key financial sources [19]. 
The structures of such enterprises are best described as diverse, including charitable organizations, community businesses, partnerships, co-operatives, unincorporated organizations, and industrial societies [19]. The private ownership logic is a key characteristic of social enterprises [12] and probably sustainable enterprises. In addition, in contrast to the perceived centrality of the founding entrepreneur, most of these businesses depended on the involvement of other individuals, organizations, committees, and volunteers. This suggests that within the social context, entrepreneurship may be a collective rather than an individual activity [19].

Sustainable enterprises create new sustainable niches or enter established ones [6]. In this sense, creativity and innovation are required, which can be manifested also in managerial actions [19]. Related to profitability, a study conducted by Shaw and Carter [19] identified that when asked about the aims of their social enterprise, none of the respondents identified profit as a key objective. In fact, after the venture launch, the majority of sustainable entrepreneurs continue to rely on public-sector grants and are cautious about adding debt to their financial issues [34]. Regarding scalability, Perrini et al. [23] argue that social entrepreneurs address the scalability of their organizational model to increase impact and induce social change.

Sustainable and social entrepreneurship differ from conventional entrepreneurship in terms of value creation and impact $[27,35]$. Over time, several forms of impact measurements have been proposed, however, impact in society is a social construction, involving different stakeholders, so it is not possible to establish a unique standard. A good framework of analysis should consider stakeholder needs in each situation [36].

In this sense, according to the situation, possible positive impacts can relate to individual lifestyle factors, social and community networks, cultural and environmental conditions, human rights, economic development, education, citizenship, and health $[11,17]$. As motivated change agents, sustainable entrepreneurs challenge institutional structures [37]. Therefore, nascent sustainable entrepreneurs with highly novel ideas would be well advised to focus on activities that can establish legitimacy and stakeholder support in the marketplace in order to produce positive impacts [13]. Therefore, sustainable entrepreneurs may provide a means of working with individuals, households, and communities to build their capabilities and resilience when facing inequalities, and thus create a more sustainable society.

\section{Materials and Methods}

Given the scarcity of dedicated research on the whole SEP [6], this study took an exploratory approach through a qualitative methodology, following the protocol suggested by the literature [38]. Because of its strengths, the case study is particularly designed for applied fields of study such as education, social work, and administration, among others, since processes, problems, and programs can be examined to understand their complex and related phenomenon. Case studies have proven particularly useful for studying innovations, programs, and informing policy [9].

A multiple case study strategy was conducted in the context of for-profit and not-for-profit organizations, in different industries and in six different countries (Brazil, Denmark, Finland, Estonia, Latvia, and Lithuania) in order to enhance the external validity of the study. A broader sample of companies of different sectors from different countries made it possible to better identify the overall nature of the entrepreneurial process or SEP. The choice of countries was based on the OECD Social Expenditure Database of 2019 [39], which had been developed in order to serve the growing need for indicators of social policy. Denmark and Finland invest more than a quarter of their GDP to public social support, occupying leading positions in the ranking. Estonia, Latvia, and Lithuania appear in intermediate positions. Brazil is not in the ranking. Therefore, the sample sought to incorporate different country characteristics in relation to their social expenditure investment, which incorporate many of the issues addressed by the United Nations Sustainable Development Goals.

Potential candidates were identified through the database of entrepreneurs and an extensive search in Google. The initial screening was based on the following criteria: (1) the entrepreneurial process must be completed (venture launched) and (2) considered to be a sustainable entrepreneurship, 
i.e., addresses economic, social, and ecological goals. The prevalence of food sector companies in the sample was largely due to the fact that there were more of them in the search, but also to the fact that their social and economic effect is potentially the greatest [29]. This initial screening rendered sixteen suitable enterprises, of which eleven agreed to participate in the study. In that context, comfort sampling was implemented in the initial phase of the empirical study. Later in the course of the study, after conducting eight interviews, it was noticeable that information from respondents began to repeat. At this point, what is called the answers redundancy stage was achieved. The researchers concluded that each subsequent answer no longer significantly added new insights about the entrepreneurial process or SEP, but decided to collect data from all eleven companies that agreed to participate in the study, and therefore it was also confirmed that the selection of the investigated companies was exhausted.

Following the theory, empirical research is based on a process approach. This means that the interview questions were structured around the temporal and cause-and-effect relationship connections between sub-parts, activities, decisions, and outcomes (outputs) of the entrepreneurial process. These sequences are described or disclosed in the Results Section.

Primary data collection was from October 2018 to January 2019. All the companies were visited for observations and personal interviews were conducted with founders and responsible people for the business. A semi-structured script was used, previously validated by Karhunen et al. [30]. In total, there was $10 \mathrm{~h}$ and $15 \mathrm{~min}$ of interviews, with an average of $56 \mathrm{~min}$ per interview. All of them were recorded and transcribed under conditions of confidentiality, and therefore quotations in this paper are anonymous. In total, 183 pages of transcription were obtained. In addition, secondary data were collected from websites, the news, scientific papers, and online publications.

Table 1 summarizes the cases studied and the data collection process.

Table 1. Cases studied.

\begin{tabular}{ccccccc}
\hline Case & Country & Industry & Type & Observation on Site & Interview Length & Secondary Data \\
\hline C1 & Estonia & Hotel & $\begin{array}{c}\text { Not-for } \\
\text { profit }\end{array}$ & Yes & $58 \mathrm{~min}$ & 8 \\
\hline C2 & Estonia & Recycle & Not-for-profit & Yes & $35 \mathrm{~min}$ & 14 \\
\hline C3 & Finland & Food sector & For-profit & Yes & $34 \mathrm{~min}$ & 12 \\
\hline C4 & Finland & Food sector & For-profit & Yes & $1 \mathrm{~h} 2 \mathrm{~min}$ & 15 \\
\hline C5 & Finland & Recycle & Not-for-profit & Yes & $1 \mathrm{~h} 4 \mathrm{~min}$ & 9 \\
\hline C6 & Lithuania & Food sector & Not-for-profit & Yes & $1 \mathrm{~h} 31 \mathrm{~min}$ & 13 \\
\hline C7 & Latvia & Food sector & Not-for-profit & Yes & $45 \mathrm{~min}$ & 10 \\
\hline C8 & Denmark & Food sector & For-profit & Yes & $1 \mathrm{~h} 8 \mathrm{~min}$ & 21 \\
\hline C9 & Brazil & Food sector & For-profit & Yes & $59 \mathrm{~min}$ & 14 \\
\hline C10 & Brazil & Food sector & For-profit & Yes & $47 \mathrm{~min}$ & 6 \\
\hline C11 & Brazil & Food sector & For-profit & Yes & $52 \mathrm{~min}$ & 9 \\
\hline
\end{tabular}

To analyze data, content analysis was applied. An initial coding was generated based on the literature $[6,14,16,21,30]$. After mapping the transcripts, information related to each category was analyzed with the help of NVivo 12 Software. Cross-case analysis searched for similarities and particularities between SEP in the analyzed cases.

\section{Results}

The results are presented according to the categories of the analysis, identified in the theoretical framework, and with observations that emerged in the field. First, each category is presented briefly, followed by more detailed results, and as a cross-case comparison, available in Table 2. 
Idea generation is the result of several propositions, which relate mainly to motivation, prior knowledge, and skills or capabilities of the entrepreneur. The ideas to start the ventures, for all the initiatives, related to the founders' past or present experiences. First, the mission-driven idea is quite strong, as it appears in individuals' motivations for all cases. It is possible to verify sensitivity towards solving a social or environmental problem as a starting point that leads to the idea. The case one owner exemplifies,

"However, maybe a reason why the sustainable thing came up was that these [marketing] events [in her previous work experience] produce a lot of waste of products and food. In this field, the waste is a big thing, because you have this one event, where it is like maybe 500 people, and they all get t-shirts, which they wear maybe once and throw it away. Many products used in these events go to waste just after it happens. There is no recycling or reuse. There is also the food waste. [... ] like one third or even sometimes, half is thrown away."

The case 11 founder gives another example,

“By 2012, every fruit my father's farm harvested was automatically delivered to the industry. At that time, there was an excess of supply. [...] The industry did not buy our fruit and it was perfect in terms of quality. Donating food in Brazil is very difficult. So, in the farm, I started to see tons of fruit on the ground. It bothered me deeply [...] I asked my father 'Can we think of a way to market this fruit also outside the industry?' My dad said, "'You can try, there's no problem.' So, I announced a $27 \mathrm{~kg}$ fruit bag on a Facebook sales page. By the time I woke up, I already had 20 requests."

Out of eleven entrepreneurs, seven entrepreneurs (cases one, two, four, five, six, nine, and 10) got inspiration for similar initiatives found throughout their trajectories. For example, the case two interviewee explains, "the idea came from Finland; they have a very similar organization there [ ... ] so the idea came from it and we started to make something similar here."

Although previous experience in entrepreneurship is not a determining characteristic (present in only three cases), all cases had previous experiences and skills in the area, either in education or in professional life. For example, the case one owner explains: "I worked for four years on event marketing field. This was a really good base, where I got a lot of experience; it helped us [... ]." Prior knowledge about the product, the service, and technology (three cases) and prior networks (three cases) are not dominant aspects related to the process of ideation in the analyzed situations.

Opportunity recognition is the output of the idea development. This silo relates to social needs, goals, and market orientation. The evaluation of the social needs and related goals of an entrepreneur, in all the cases analyzed, are somehow moderated by entrepreneurial knowledge and the recognition of a solution to a problem, because of the previous process. All cases relate to market imperfections contributing to ecological and social problems that the entrepreneurs perceived as opportunities to introduce a value-adding solution to the marketplace. However, not all cases have the motivation related to personal gain, such as earning money, since five cases (one, two, five, six, and seven) are not-for-profit organizations, as shown in the opportunity development category in Table 2. Case six exemplifies this, once the initial intention was to do only a single action, which eventually evolved into an organization. Most of these businesses (nine cases) operate only in the domestic market.

Social and environmental concern stands out in relation to financial aspects in most of the cases, although financial aspects are essential to the survival of an organization. In six situations (cases three, four, eight, nine, 10, and 11), the founders seek personal gains and intertwine this with benefits to society. The case three interviewee explains, "The company already works with solutions to waste, so we have some experience in the field and business. [ ... ] We perceived the situation as a new market opportunity to increase our market participation and sustainability in society at the same time". The case four interviewee says, "the same business model was present in other countries and also in Finland, but we saw that, at that moment, companies in the market had failures and we wanted to do it better." One of the founders of case nine also gives a good example, 
"In 2014, I started a post graduate degree in business, focusing on sustainability. [...] I began to see several businesses based on conscious capitalism, i.e., you do not have to do something just to profit; you can help an entire supply chain, the ecosystem, everything around you. Then we thought about it. So, as my parents are small farmers, I already knew the dynamics of these small producers, how much they are exploited by food supply chain, so we decided to work with solutions to them, helping society with a business that is also profitable."

Opportunity development is the outcome of several activities related to the business concept development, such as marketing mix, business model, and available resources. At this stage, the results were very homogeneous between cases. The product or service, market, and target group or accessibility, in all cases analyzed, were a continuation of the idea, social needs, and goals, i.e., there were just small changes throughout the entrepreneurial process. This may relate to the fact that almost none of these entrepreneurs either tested the product or service previously, or made a business plan. The only exception is case 10, the one company that made a business plan. It was incubated for one year and tested the product before venture launch, making changes based on it, however, this was a unique case.

Available resources related to the use of knowledge, technology, third-party solidarity and collaboration, and the creativity of the entrepreneurs. For example, the case one owner says, "basically, at the beginning, we were building everything; we were using waste and abandoned things and transforming it." This was also reflected in the market entry strategy, which was based on direct contact or virtual mechanisms to reach possible customers. This aspect continued in the promotion activity, which had a lot of informal disclosures to customers (in most cases "word of mouth"), public campaigns with the help of volunteers and partnerships with other stakeholders, and the strong use of social media. The price was particular to each case, according to the product or service, with two situations in which the final consumers would not be charged because they were Non-Governmental Organisations-NGOs (cases six and seven), with resources coming from other stakeholders or services.

The translation of the social and ecological goal into customer benefits, i.e., the integration of the triple bottom line was a very interesting aspect. In most situations (cases one, two, three, four, five, eight, nine, 10, and 11), both dimensions were integrated at the same time, however, although both aspects were present, in the beginning the focus of the business was only on the environmental dimension in cases one, two, three, four, five, eight, 10, and 11. Case nine is the only situation where both dimensions had the same focus. The case five interviewee informed, "Our main goal is environmental, since the beginning. This is our focus. But the social thing comes as a consequence of the business idea and operations; we also have it since the beginning." In cases six and seven, the opposite situation was verified, since the dimensions were integrated in separate moments, first the social and, then, the environmental dimension. Although both aspects are present currently, the priority for these two cases is the social aspects. The case six interviewee explains,

"In the beginning, we were just a partner in a governmental program distributing the food parcels for poor people, but after some years we started expanding a lot, as we started to work more on the food waste issues [ ... ] by that time [in the beginning], food waste wasn't kind of a popular theme, actually no one cared about it. Nowadays, things change and our purpose is a two-fold mission, like combat the food waste by combating the poor or combat the poor by fighting the food waste. Is there any part more important than that? Here we agreed as a team that social issues are more important. It is ok, because all those motivations are here also."

Venture launch and business exploitation are the next stages. The usual entrepreneurial process ends with the venture launch. For this reason, results are presented in two different categories as follows: venture launch, which generally should end the analysis of the entrepreneurial process and environmental and social impact, as a new category related to SEP.

Venture launch involves the formation of strategies, acquiring any missing tangible and intangible resources, teambuilding, and the legal formation of the organizations. Table 2 shows the year of emergence for each case. Most of the organizations emerge in the legal form of private companies. 
The rest are NGOs. NGOs are usually not-for-profit (cases one, two, six, and seven). Private companies are for profit (three, four, eight, nine, 10 and 11), but there is a case of a private company that is not-for-profit (case five). The choice in all situations occurred for legal reasons combined with the objectives of the entrepreneurs, and also considered the context of the country where they operated.

Financial resources, as well as intangible and tangible resources are consequences of the previous phases, because most of the cases started without financial resources, using intangible ones, such as knowledge, virtual services, social networks, residential structure, and voluntary partnerships or services. The case 2 interviewee explains, "At the beginning, there was just voluntary work. Also, people brought donations for us. We made a rental agreement, the first three months were free, and then we started to pay rent. So, in the fourth month, we already had some money from sales that we could pay the rent."

Finally, environmental and social impact emerge as new categories, since these characteristics differentiate these ventures from regular businesses. Each business has its specific impact, as Table 2 details. All the analyzed cases present both environmental and social impacts in the regions they operate and these organizations measure and communicate this. The case two owner interviewee reports,

"For example, last year we saved 1500 tons of textiles from the landfill, so we can measure our impact directly [ ... ] we also try to help homeless people. For example, we organize for them, many times a year, something like a shopping night. All the homeless people come here one evening and they can shop free. They can choose anything from our shop for free."

Cases two and five, cases six and seven, and cases nine and 10 present the same products or services, and therefore they produce very similar environmental and social impacts, varying in quantities according to the organization's size and region attended. Some small differences also occur. For example, case five produces social impact by recruiting and providing training for people who have been out of the labor market for years or who are in a drug rehabilitation process, as part of a collaboration policy with the Finnish government.

Related to impacts produced, the case four owner interviewee explains,

"We saved more than 1,100,000 portions of food to go to waste since our begging. We have a few ways to measure it in kilograms and in $\mathrm{CO} 2$ saved, based on published studies in Finland. We estimate it to be approximately 430 tons of food and 2.7 million kilograms of $\mathrm{CO} 2$ emission reduced. Of course, the number of portions of food saved from waste is based on our operations. The kilograms and CO2 saved are based on an estimative."

The case seven interviewee provides information measurement in their annual report: "Last year, we redistributed 40 tons of food. How many people have we helped? We helped 23,000 low income people, on average one parent family with two children, single mother with an average income of 350 euros." The case eight interviewee explains, "[ . . ] because one of our primary KPIs and goals, a movement is actually being built, [ ... ] it's a really big goal on creating that movement and having that scaled organically, without us having to be the primary motor, or the engine."

The case 11 founder gives another explanation,

"We have rescued more than five tons of food in this year of operation. [...] The farmer was also a layman in that. At first, it was very difficult to buy from them, they just wanted to donate the food to us. They did not want to sell, but we try to work with a fairer and transparent market, so not selling would be unfair to them. We had to "educate" the farmer too, so today it's easier. We now decide the value of the food together. We provide education campaigns also to consumers. I think both social and environmental are our social impact, at the same time, because we are reducing food waste."

All the organizations analyzed have financial sustainability, which is also expected in a regular business. Finally, the problems faced, and plans, in most cases, relate directly to the impact produced by these organizations, as shown in Table 2 .

Table 2 presents detailed information and cross-case analysis for all cases. 
Table 2. General results and cross-case comparison.

\begin{tabular}{|c|c|c|c|c|c|}
\hline \multicolumn{6}{|c|}{ Propositions $\rightarrow$ Idea Generation } \\
\hline Cases & Where Did the Idea Come from? & $\begin{array}{l}\text { Prior Experience in } \\
\text { Entrepreneurship }\end{array}$ & $\begin{array}{l}\text { Prior Experiences and } \\
\text { Skills in the Area(s) }\end{array}$ & $\begin{array}{l}\text { Prior Knowledge of } \\
\text { Product, Service or Tech }\end{array}$ & Prior Networks \\
\hline $\mathrm{C} 1$ & $\begin{array}{l}\text { One of the owners has always had an interest in themes related to nature since } \\
\text { childhood. She and her partner decided to travel for a year to find inspiration for } \\
\text { the business. Along the way, they visited different eco-hostels and found the idea } \\
\text { interesting. They thought this would also help by raising awareness of the issue in } \\
\text { the local population towards sustainable living possibilities. As the owner } \\
\text { worked some years in marketing events, she attributes this experience also as the } \\
\text { reason why the sustainable thing came up, since at these events people generated } \\
\text { a lot of waste and she was always looking for solutions for this. }\end{array}$ & No & $\begin{array}{l}\text { Yes, studied tourism } \\
\text { management. } \\
\text { Worked for four years on } \\
\text { marketing events. }\end{array}$ & No & No \\
\hline C2 & $\begin{array}{l}\text { The idea came from a similar organization in another country, which inspired the } \\
\text { whole mission of the organization, since the country was facing the same problem } \\
\text { that could be solved in the same way. }\end{array}$ & No & $\begin{array}{l}\text { Yes, one of them studied } \\
\text { business and marketing. } \\
\text { The other works in an } \\
\text { environmental } \\
\text { protection agency. }\end{array}$ & No & $\begin{array}{l}\text { Yes, related to } \\
\text { charities }\end{array}$ \\
\hline $\mathrm{C} 3$ & $\begin{array}{l}\text { The idea came from a company that already works with waste and recycling. } \\
\text { The managers realized that the food waste is no longer a threat, but a market } \\
\text { opportunity, since } 10 \% \text { to } 25 \% \text { of the food offered in buffet restaurants in the } \\
\text { country is going to waste. }\end{array}$ & Yes & $\begin{array}{l}\text { Yes, business } \\
\text { management in the } \\
\text { recycling and waste } \\
\text { sector }\end{array}$ & No & Yes \\
\hline $\mathrm{C} 4$ & $\begin{array}{l}\text { Almost all founders knew each other beforehand. They were willing to start a } \\
\text { business, and some of them had a special focus on sustainability issues. They saw } \\
\text { some initiatives dealing with the core of their business elsewhere and thought } \\
\text { they could improve it and do better. In addition, society was beginning to discuss } \\
\text { the subject more, which would make it easier to have clients. }\end{array}$ & Yes & $\begin{array}{l}\text { Yes, education in } \\
\text { computer science, which } \\
\text { is the core of the business }\end{array}$ & $\begin{array}{l}\text { Yes, experience in } \\
\text { information technology and } \\
\text { digital business industry. }\end{array}$ & $\begin{array}{l}\text { Yes, with angel } \\
\text { investors, } \\
\text { who participated in } \\
\text { the expansion process }\end{array}$ \\
\hline C5 & $\begin{array}{l}\text { A similar initiative, that took place in another country facing the same situation, } \\
\text { inspired the idea. }\end{array}$ & No & $\begin{array}{l}\text { Yes, education on } \\
\text { environmental } \\
\text { conservation }\end{array}$ & $\begin{array}{l}\text { Yes, on nature conservation } \\
\text { association }\end{array}$ & No \\
\hline $\mathrm{C} 6$ & $\begin{array}{l}\text { During a trip abroad, the founder discovered an organization and thought he } \\
\text { could make an equal initiative in the country. Initially, the idea was to make a } \\
\text { unique, charitable event, to help people in the community, during the cold winter } \\
\text { season. As the initiatives were recurring, the formal organization naturally } \\
\text { emerged. }\end{array}$ & No & $\begin{array}{l}\text { Yes, manager in a } \\
\text { multinational company } \\
\text { in the food sector for six } \\
\text { years. }\end{array}$ & $\begin{array}{l}\text { Knowledge related to the } \\
\text { food sector and corporate } \\
\text { social responsibility. }\end{array}$ & No \\
\hline
\end{tabular}


Table 2. Cont.

\begin{tabular}{|c|c|c|c|c|c|}
\hline \multicolumn{6}{|c|}{ Propositions $\rightarrow$ Idea Generation } \\
\hline Cases & Where Did the Idea Come from? & $\begin{array}{l}\text { Prior Experience in } \\
\text { Entrepreneurship }\end{array}$ & $\begin{array}{l}\text { Prior Experiences and } \\
\text { Skills in the Area(s) }\end{array}$ & $\begin{array}{c}\text { Prior Knowledge of } \\
\text { Product, Service or Tech }\end{array}$ & Prior Networks \\
\hline $\mathrm{C} 7$ & $\begin{array}{l}\text { The organization emerged as an answer to the economic crisis faced in the country. } \\
\text { Many people lost their jobs and did not have any money for food. As the social } \\
\text { care system was overloaded, people started to go to charity organizations to ask } \\
\text { for help. In this context, two big NGOs decided to come together and funded a } \\
\text { new organization to help these people. }\end{array}$ & Yes & $\begin{array}{l}\text { Yes, education in } \\
\text { economics }\end{array}$ & No & No \\
\hline $\mathrm{C} 8$ & $\begin{array}{l}\text { The founders were having dinner in a restaurant at the time of closing and saw } \\
\text { the employees cleaning the place and discarding food that was not consumed. } \\
\text { They realized that it was a very large amount of food and that it was tasty. } \\
\text { That bothered them, so they began to think in ways to solve it. }\end{array}$ & No & $\begin{array}{l}\text { Yes, education in } \\
\text { programming and } \\
\text { business }\end{array}$ & No & No \\
\hline C9 & $\begin{array}{l}\text { The founder was doing a postgraduate degree in business management when he } \\
\text { was first exposed to the idea of conscious capitalism in entrepreneurship, i.e., that } \\
\text { he could make a business to both profit and help society. He decided to start a } \\
\text { business to reduce food waste, mostly based on his personal history and after } \\
\text { meeting producers who faced this problem. He began to read about other } \\
\text { businesses. }\end{array}$ & No & $\begin{array}{l}\text { Yes, studied business } \\
\text { management with focus } \\
\text { on sustainability } \\
\text { (post-graduation) }\end{array}$ & No & No \\
\hline C10 & $\begin{array}{l}\text { The founder realized that supermarkets have some commercial practices of } \\
\text { accepting or rejecting fresh food based on its aesthetic standard in terms of size } \\
\text { and symmetry. This is usually called "imperfect produce". She talked about this } \\
\text { problem with her grandfather, who has experience in planting food. } \\
\text { Her grandfather's response influenced her to work on promoting solutions to this } \\
\text { problem through entrepreneurship: "I asked the nearest person that had } \\
\text { knowledge in these issues. 'Okay, but what is imperfect in your garden?' He told } \\
\text { me: 'Nature does not have imperfections.' Whatever I get in my garden, I } \\
\text { consume. Nothing is rubbish because it is bigger, smaller or looks different". }\end{array}$ & No & $\begin{array}{l}\text { Yes, education in } \\
\text { business }\end{array}$ & No & No \\
\hline $\mathrm{C} 11$ & $\begin{array}{l}\text { Due to an oversupply, the industry rejected the product from her father's farm. } \\
\text { Although perfect for consumption, the fruits were thrown on the farm floor to rot. } \\
\text { The founder saw tons of food wasted and was deeply dissatisfied with the } \\
\text { problem. Then, she began to think of solutions to this problem. }\end{array}$ & No & $\begin{array}{l}\text { Yes, her father owns a } \\
\text { farm and she help in the } \\
\text { marketing process }\end{array}$ & $\begin{array}{l}\text { Yes, knowledge related to the } \\
\text { food sector }\end{array}$ & No \\
\hline
\end{tabular}


Table 2. Cont

\begin{tabular}{|c|c|c|c|}
\hline \multicolumn{4}{|c|}{ Idea Development $\rightarrow$ Opportunity Recognition } \\
\hline Cases & Social Needs/Target Group & Goal & Market Orientation \\
\hline $\mathrm{C} 1$ & Tourists and students from local university & $\begin{array}{l}\text { To provide a more sustainable living, by coming up with more affordable prices } \\
\text { accommodations and based on environmentally friendly process }\end{array}$ & Domestic \\
\hline $\mathrm{C} 2$ & $\begin{array}{l}\text { Citizens of different social classes that seek to reuse/recycle } \\
\text { for environmental, social or financial reasons }\end{array}$ & $\begin{array}{l}\text { To make reuse and recycling as a normal everyday habit in the country, i.e., to take out of } \\
\text { the garbage those things that are still usable and put them in circulation again }\end{array}$ & Domestic \\
\hline $\mathrm{C} 3$ & $\begin{array}{l}\text { Food sector companies that have a commercial kitchen and } \\
\text { produce some food waste }\end{array}$ & $\begin{array}{l}\text { To give concrete solutions for the food waste problem in commercial kitchens by } \\
\text { promoting the wise use of resources }\end{array}$ & Domestic \\
\hline $\mathrm{C} 4$ & $\begin{array}{l}\text { Retail, restaurants, coffee shops or grocery stores with } \\
\text { surplus food and consumers concerned with environmental } \\
\text { issues and or with less economic condition }\end{array}$ & To develop and maintain digital marketplace for surplus food & International \\
\hline C5 & $\begin{array}{l}\text { Citizens of different social classes that seek to reuse/recycle } \\
\text { for environmental or financial reasons }\end{array}$ & To make reuse and recycling as a purpose of preserving the environment & Domestic \\
\hline $\mathrm{C} 6$ & Socially disadvantaged people & $\begin{array}{l}\text { To work as a mediator, collecting donated food from retailers, producers, public and } \\
\text { providing them to the poor people. }\end{array}$ & Domestic \\
\hline C7 & Socially disadvantaged people & $\begin{array}{l}\text { To work as a mediator, collecting donated food from retailers, producers, public and } \\
\text { providing them to the poor people. }\end{array}$ & Domestic \\
\hline $\mathrm{C} 8$ & $\begin{array}{l}\text { Retail, restaurants, coffee shops or grocery stores with } \\
\text { surplus food and consumers concerned with environmental } \\
\text { issues and/or less economic condition }\end{array}$ & To develop and maintain digital and physical marketplace for surplus food & International \\
\hline C9 & Consumers concerned with environmental and social issues & $\begin{array}{l}\text { To develop and maintain digital marketplace for the delivery of baskets containing } \\
\text { non-standard compliance and surplus food from producers }\end{array}$ & Domestic \\
\hline C10 & $\begin{array}{l}\text { Consumers or companies seeking convenience by receiving } \\
\text { food at home/workplace and/or consumers concerned with } \\
\text { environmental and social issues }\end{array}$ & $\begin{array}{l}\text { To develop and maintain digital marketplace for the delivery of baskets containing } \\
\text { general food, including non-standard compliance and surplus food from producers }\end{array}$ & Domestic \\
\hline C11 & $\begin{array}{l}\text { Consumers or companies seeking convenience by receiving } \\
\text { food at home/workplace }\end{array}$ & $\begin{array}{l}\text { To develop and maintain digital marketplace for the delivery of fruits, including } \\
\text { non-standard compliance and surplus food from one producer }\end{array}$ & Domestic \\
\hline
\end{tabular}


Table 2. Cont.

\begin{tabular}{|c|c|c|c|c|c|c|c|c|c|}
\hline \multicolumn{10}{|c|}{ Concept Development $\rightarrow$ Opportunity Development } \\
\hline Cases & $\begin{array}{l}\text { Business } \\
\text { Plan }\end{array}$ & Business Model & $\begin{array}{l}\text { Value Proposition } \\
\text { X Triple-Bottom } \\
\text { Approach }\end{array}$ & Product/Service & $\begin{array}{c}\text { Market and Target } \\
\text { Group; } \\
\text { Accessibility }\end{array}$ & Price & Promotion & Available Resources & $\begin{array}{l}\text { Environmental and } \\
\text { Social Aspects }\end{array}$ \\
\hline C1 & No & $\begin{array}{l}\text { Mix of regular } \\
\text { business model } \\
\text { with NGO, since it } \\
\text { is a not-for-profit } \\
\text { hostel; business to } \\
\text { consumer }\end{array}$ & $\begin{array}{l}\text { Sharing of } \\
\text { intangible values, } \\
\text { lower prices, } \\
\text { engage multiple } \\
\text { stakeholders, } \\
\text { consumer } \\
\text { education. }\end{array}$ & $\begin{array}{l}\text { Hostel that promotes the } \\
\text { concept of sustainable } \\
\text { living, operating based } \\
\text { on environmental } \\
\text { solutions with a more } \\
\text { affordable price. It also } \\
\text { offers } \\
\text { sustainability-related } \\
\text { workshops }\end{array}$ & $\begin{array}{l}\text { Tourists or students } \\
\text { of the local } \\
\text { university }\end{array}$ & $\begin{array}{l}\text { More affordable } \\
\text { price than regular } \\
\text { hostels }\end{array}$ & $\begin{array}{l}\text { Informal disclosure } \\
\text { by friends and } \\
\text { customers and also } \\
\text { in the hotel booking } \\
\text { platform }\end{array}$ & $\begin{array}{l}\text { Without financial } \\
\text { resources, they set up } \\
\text { the place by recycling } \\
\text { furniture taken from } \\
\text { garbage or donations. } \\
\text { The owner of the } \\
\text { building gave } 6 \text { months } \\
\text { of rent exemption. }\end{array}$ & $\begin{array}{l}\text { Both dimensions were } \\
\text { integrated, since the } \\
\text { beginning, at the same } \\
\text { time, however, } \\
\text { the focus is on the } \\
\text { environmental } \\
\text { dimension since they } \\
\text { began. }\end{array}$ \\
\hline $\mathrm{C} 2$ & No & $\begin{array}{l}\text { Mix of regular } \\
\text { business model } \\
\text { with NGO, since } \\
\text { the company does } \\
\text { not receive external } \\
\text { resources; business } \\
\text { to consumers }\end{array}$ & $\begin{array}{l}\text { Sharing of } \\
\text { intangible values, } \\
\text { lower prices, } \\
\text { consumer education }\end{array}$ & $\begin{array}{l}\text { Collection of products } \\
\text { that are no longer used, } \\
\text { repaired if necessary, } \\
\text { and resold }\end{array}$ & $\begin{array}{l}\text { Citizens of different } \\
\text { social classes in the } \\
\text { country }\end{array}$ & $\begin{array}{l}\text { Cheaper price for } \\
\text { second-hand } \\
\text { products }\end{array}$ & $\begin{array}{l}\text { Posters and public } \\
\text { campaigns, with } \\
\text { voluntary work of } \\
\text { marketing agencies }\end{array}$ & $\begin{array}{l}\text { Only a small shop } \\
\text { place rented with three } \\
\text { months of rent } \\
\text { exemption and } \\
\text { volunteer work in the } \\
\text { beginning }\end{array}$ & $\begin{array}{l}\text { Both dimensions were } \\
\text { integrated, since the } \\
\text { beginning, at the same } \\
\text { time, however, } \\
\text { the organization exists } \\
\text { exclusively for } \\
\text { environmental } \\
\text { purposes. }\end{array}$ \\
\hline C3 & No & $\begin{array}{l}\text { Regular business } \\
\text { model, business to } \\
\text { business }\end{array}$ & $\begin{array}{l}\text { Decreasing } \\
\text { operational costs, } \\
\text { increasing } \\
\text { reputation, } \\
\text { employee's } \\
\text { awareness and } \\
\text { education }\end{array}$ & $\begin{array}{l}\text { Digital platform that } \\
\text { helps kitchens to } \\
\text { measure the food waste, } \\
\text { understand what it is, } \\
\text { why it has occurred, } \\
\text { and to find possible } \\
\text { solutions. }\end{array}$ & $\begin{array}{l}\text { Restaurants, hotels, } \\
\text { schools, other } \\
\text { commercial } \\
\text { kitchens }\end{array}$ & $\begin{array}{l}\text { Confidential } \\
\text { information }\end{array}$ & $\begin{array}{l}\text { As the service is } \\
\text { quite new, } \\
\text { the company made } \\
\text { a strong investment } \\
\text { on a marketing } \\
\text { campaign with } \\
\text { possible customers }\end{array}$ & $\begin{array}{l}\text { The business is part of } \\
\text { a larger company, from } \\
\text { which it uses the } \\
\text { physical structure, } \\
\text { expertise and network }\end{array}$ & $\begin{array}{l}\text { Both dimensions were } \\
\text { integrated, since the } \\
\text { beginning, at the same } \\
\text { time, however, } \\
\text { the focus is only on the } \\
\text { environmental } \\
\text { dimension. }\end{array}$ \\
\hline C4 & No & $\begin{array}{l}\text { Classic market } \\
\text { placement, purely } \\
\text { commission driven; } \\
\text { Both business to } \\
\text { business and } \\
\text { business to } \\
\text { consumer }\end{array}$ & $\begin{array}{l}\text { Sharing of } \\
\text { intangible values, } \\
\text { lower prices, } \\
\text { convenience, } \\
\text { engage multiple } \\
\text { stakeholders, } \\
\text { consumer education }\end{array}$ & $\begin{array}{l}\text { A digital platform to } \\
\text { connect sellers that have } \\
\text { food surplus with } \\
\text { consumers, providing } \\
\text { food at lower costs. }\end{array}$ & $\begin{array}{l}\text { Businesses such as } \\
\text { retail, restaurants, } \\
\text { coffee shops or } \\
\text { grocery stores; and } \\
\text { final consumers }\end{array}$ & $\begin{array}{l}\text { Commission for } \\
\text { every transaction, } \\
\text { no fixed fees }\end{array}$ & $\begin{array}{l}\text { Educational } \\
\text { campaigns, social } \\
\text { media, regular } \\
\text { media }\end{array}$ & $\begin{array}{l}\text { Knowledge, since most } \\
\text { of the solutions } \\
\text { provided by the } \\
\text { company is virtual and } \\
\text { knowledge intensive }\end{array}$ & $\begin{array}{l}\text { Both dimensions were } \\
\text { integrated, since the } \\
\text { beginning, at the same } \\
\text { time, however, } \\
\text { the focus is on the } \\
\text { environmental } \\
\text { dimension. }\end{array}$ \\
\hline
\end{tabular}


Table 2. Cont.

\begin{tabular}{|c|c|c|c|c|c|c|c|c|c|}
\hline \multicolumn{10}{|c|}{ Concept Development $\rightarrow$ Opportunity Development } \\
\hline Cases & $\begin{array}{l}\text { Business } \\
\text { Plan }\end{array}$ & Business Model & $\begin{array}{l}\text { Value Proposition } \\
\text { X Triple-Bottom } \\
\text { Approach }\end{array}$ & Product/Service & $\begin{array}{c}\text { Market and Target } \\
\text { Group; } \\
\text { Accessibility }\end{array}$ & Price & Promotion & Available Resources & $\begin{array}{l}\text { Environmental and } \\
\text { Social Aspects }\end{array}$ \\
\hline C5 & No & $\begin{array}{l}\text { Mix of regular } \\
\text { business model } \\
\text { with NGO, since it } \\
\text { is not-for-profit; } \\
\text { business to } \\
\text { consumers }\end{array}$ & $\begin{array}{l}\text { Sharing of } \\
\text { intangible values, } \\
\text { lower prices, } \\
\text { consumer education }\end{array}$ & $\begin{array}{l}\text { Collection of products } \\
\text { that are no longer used, } \\
\text { repaired if necessary, } \\
\text { and resold. They also } \\
\text { promote training and } \\
\text { consulting in the } \\
\text { environmental field }\end{array}$ & $\begin{array}{l}\text { Citizens of different } \\
\text { social classes in the } \\
\text { country }\end{array}$ & $\begin{array}{l}\text { Cheaper price for } \\
\text { second-hand } \\
\text { products }\end{array}$ & $\begin{array}{l}\text { In the beginning, } \\
\text { word of mouth, now, } \\
\text { integrated social } \\
\text { media }\end{array}$ & $\begin{array}{l}\text { Partnerships and } \\
\text { volunteer work }\end{array}$ & $\begin{array}{l}\text { Both social and } \\
\text { environmental aspects } \\
\text { started at the same } \\
\text { time, but the } \\
\text { organization exists for } \\
\text { environmental reasons }\end{array}$ \\
\hline C6 & No & Charity NGO & $\begin{array}{l}\text { Sharing of } \\
\text { intangible values, } \\
\text { convenience, } \\
\text { engage multiple } \\
\text { stakeholders, } \\
\text { consumer education }\end{array}$ & $\begin{array}{l}\text { Recovery and } \\
\text { redistribution of food } \\
\text { that would be wasted by } \\
\text { actors in the food supply } \\
\text { chain or which were } \\
\text { harvested in campaigns } \\
\text { to socially } \\
\text { disadvantaged people. }\end{array}$ & $\begin{array}{l}\text { People or } \\
\text { organizations } \\
\text { dealing with } \\
\text { socially } \\
\text { disadvantaged } \\
\text { people }\end{array}$ & Free & $\begin{array}{l}\text { Social networks, } \\
\text { retail campaigns, } \\
\text { media campaigns, } \\
\text { donor events, } \\
\text { and marathons in } \\
\text { the country. }\end{array}$ & $\begin{array}{l}\text { Agreements with } \\
\text { different suppliers, } \\
\text { venture capital, social } \\
\text { and community } \\
\text { volunteer work }\end{array}$ & $\begin{array}{l}\text { Started only with the } \\
\text { social dimension. } \\
\text { Environmental aspects } \\
\text { were integrated after. } \\
\text { Nowadays, both } \\
\text { dimensions are } \\
\text { intertwined, however, } \\
\text { the priority is the social } \\
\text { aspect. }\end{array}$ \\
\hline $\mathrm{C} 7$ & No & Charity NGO & $\begin{array}{l}\text { Sharing of } \\
\text { intangible values, } \\
\text { convenience, } \\
\text { engage multiple } \\
\text { stakeholders, } \\
\text { consumer education }\end{array}$ & $\begin{array}{l}\text { Recovery and } \\
\text { redistribution of food } \\
\text { that would be wasted by } \\
\text { actors in the food supply } \\
\text { chain or which were } \\
\text { harvested in campaigns } \\
\text { to socially } \\
\text { disadvantaged people. }\end{array}$ & $\begin{array}{l}\text { People or } \\
\text { organizations } \\
\text { dealing with } \\
\text { socially } \\
\text { disadvantaged } \\
\text { people }\end{array}$ & $\begin{array}{l}\text { Free-now they } \\
\text { are organizing to } \\
\text { charge a small fee }\end{array}$ & $\begin{array}{l}\text { Campaigns in the } \\
\text { city for food } \\
\text { donations, contact } \\
\text { with retail and } \\
\text { social media }\end{array}$ & $\begin{array}{l}\text { Infrastructure, } \\
\text { expertise, contacts and } \\
\text { also, partially, } \\
\text { the money of the } \\
\text { "umbrella" NGO }\end{array}$ & $\begin{array}{l}\text { Started only with the } \\
\text { social dimension. } \\
\text { Environmental aspects } \\
\text { were integrated after. } \\
\text { Nowadays, both } \\
\text { dimensions are } \\
\text { intertwined, however, } \\
\text { the priority is the social } \\
\text { aspect. }\end{array}$ \\
\hline C8 & No & $\begin{array}{l}\text { Classic market } \\
\text { placement, purely } \\
\text { commission driven; } \\
\text { Both business to } \\
\text { business and } \\
\text { business to } \\
\text { consumer }\end{array}$ & $\begin{array}{l}\text { Sharing of } \\
\text { intangible values, } \\
\text { lower prices, } \\
\text { convenience, } \\
\text { engage multiple } \\
\text { stakeholders, } \\
\text { consumer education }\end{array}$ & $\begin{array}{l}\text { A digital platform to } \\
\text { connect sellers that have } \\
\text { food surplus with } \\
\text { consumers, providing } \\
\text { food at lower costs. } \\
\text { Also, a physical and } \\
\text { virtual store where they } \\
\text { sell surplus or close to } \\
\text { expire food from } \\
\text { producers and industry, } \\
\text { and also food with small } \\
\text { packaging errors }\end{array}$ & $\begin{array}{l}\text { Businesses such as } \\
\text { retail, restaurants, } \\
\text { coffee shops or } \\
\text { grocery stores, } \\
\text { flower shops and } \\
\text { final consumer }\end{array}$ & $\begin{array}{l}\text { Commission for } \\
\text { every transaction. } \\
\text { No fixed fees }\end{array}$ & $\begin{array}{l}\text { Educational } \\
\text { campaigns, social } \\
\text { media, regular } \\
\text { media, educational } \\
\text { personal projects in } \\
\text { schools and events }\end{array}$ & $\begin{array}{l}\text { Knowledge, since most } \\
\text { of the initial solutions } \\
\text { provided by the } \\
\text { company is virtual and } \\
\text { knowledge intensive. }\end{array}$ & $\begin{array}{l}\text { Both dimensions were } \\
\text { integrated, since the } \\
\text { beginning, at the same } \\
\text { time, however, } \\
\text { the focus is mostly on } \\
\text { the environmental } \\
\text { dimension. }\end{array}$ \\
\hline
\end{tabular}


Table 2. Cont.

\begin{tabular}{|c|c|c|c|c|c|c|c|c|c|}
\hline \multicolumn{10}{|c|}{ Concept Development $\rightarrow$ Opportunity Development } \\
\hline Cases & $\begin{array}{l}\text { Business } \\
\text { Plan }\end{array}$ & Business Model & $\begin{array}{l}\text { Value Proposition } \\
\text { X Triple-Bottom } \\
\text { Approach }\end{array}$ & Product/Service & $\begin{array}{c}\text { Market and Target } \\
\text { Group; } \\
\text { Accessibility }\end{array}$ & Price & Promotion & Available Resources & $\begin{array}{l}\text { Environmental and } \\
\text { Social Aspects }\end{array}$ \\
\hline C9 & No & $\begin{array}{l}\text { Regular business } \\
\text { model, business to } \\
\text { consumer }\end{array}$ & $\begin{array}{l}\text { Sharing of } \\
\text { intangible values, } \\
\text { lower prices, } \\
\text { convenience, } \\
\text { engage multiple } \\
\text { stakeholders, } \\
\text { consumer education }\end{array}$ & $\begin{array}{l}\text { A digital platform that } \\
\text { sells monthly food } \\
\text { baskets subscription to } \\
\text { consumers for a lower } \\
\text { price. These products } \\
\text { would be discarded by } \\
\text { producers for } \\
\text { non-standard } \\
\text { compliance or absence of } \\
\text { a market }\end{array}$ & $\begin{array}{l}\text { Final consumers of } \\
\text { different social } \\
\text { classes }\end{array}$ & $\begin{array}{l}\text { Cheaper price, } \\
\text { because these are } \\
\text { products that } \\
\text { would be } \\
\text { discarded }\end{array}$ & $\begin{array}{l}\text { Word of mouth, } \\
\text { social media, regular } \\
\text { media, educational } \\
\text { personal projects in } \\
\text { schools, companies, } \\
\text { and food events }\end{array}$ & $\begin{array}{l}\text { Without financial } \\
\text { resources, the business } \\
\text { started at the founders' } \\
\text { home, with a website } \\
\text { developed by them and } \\
\text { using their personal car } \\
\text { for deliveries }\end{array}$ & $\begin{array}{l}\text { Both dimensions were } \\
\text { integrated, since the } \\
\text { beginning, at the same } \\
\text { time with the same } \\
\text { focus. }\end{array}$ \\
\hline C10 & Yes & $\begin{array}{l}\text { Regular business } \\
\text { model, business to } \\
\text { consumer and } \\
\text { business to } \\
\text { business }\end{array}$ & $\begin{array}{l}\text { Sharing of } \\
\text { intangible values, } \\
\text { lower prices, } \\
\text { convenience, } \\
\text { engage multiple } \\
\text { stakeholders, } \\
\text { consumer education }\end{array}$ & $\begin{array}{l}\text { A digital platform that } \\
\text { sells monthly food } \\
\text { baskets subscription to } \\
\text { consumers for a lower } \\
\text { price. These products } \\
\text { would be discarded by } \\
\text { producers for } \\
\text { non-standard } \\
\text { compliance or absence of } \\
\text { a market }\end{array}$ & $\begin{array}{l}\text { Final consumers of } \\
\text { different social } \\
\text { classes and } \\
\text { companies buying } \\
\text { for their employees }\end{array}$ & $\begin{array}{l}\text { Cheaper price, } \\
\text { because the } \\
\text { baskets include } \\
\text { products that } \\
\text { would be } \\
\text { discarded }\end{array}$ & $\begin{array}{l}\text { Social media, } \\
\text { posters in } \\
\text { restaurants, regular } \\
\text { media, and food } \\
\text { events }\end{array}$ & $\begin{array}{l}\text { Without financial } \\
\text { resources, the business } \\
\text { started at the founders' } \\
\text { home }\end{array}$ & $\begin{array}{l}\text { Both dimensions were } \\
\text { integrated, since the } \\
\text { beginning, at the same } \\
\text { time, however, } \\
\text { the focus is mostly on } \\
\text { the environmental } \\
\text { dimension. }\end{array}$ \\
\hline C11 & No & $\begin{array}{l}\text { Regular business } \\
\text { model, business to } \\
\text { consumer and } \\
\text { business to } \\
\text { business }\end{array}$ & $\begin{array}{l}\text { Sharing of } \\
\text { intangible values, } \\
\text { lower prices, } \\
\text { convenience, } \\
\text { engage multiple } \\
\text { stakeholders, } \\
\text { consumer education }\end{array}$ & $\begin{array}{l}\text { A digital platform that } \\
\text { sells single purchases or } \\
\text { monthly subscription to } \\
\text { consumers for a lower } \\
\text { price. These products } \\
\text { would be discarded by } \\
\text { producers for } \\
\text { non-standard } \\
\text { compliance or absence of } \\
\text { a market }\end{array}$ & $\begin{array}{l}\text { Final consumers of } \\
\text { different social } \\
\text { classes and } \\
\text { restaurants or } \\
\text { commercial } \\
\text { kitchens }\end{array}$ & $\begin{array}{l}\text { Cheaper price } \\
\text { because the } \\
\text { baskets include } \\
\text { products that } \\
\text { would be } \\
\text { discarded }\end{array}$ & $\begin{array}{l}\text { Word of mouth, } \\
\text { social media, } \\
\text { and regular media }\end{array}$ & $\begin{array}{l}\text { Without financial } \\
\text { resources, the business } \\
\text { started by selling the } \\
\text { product on a Facebook } \\
\text { sales page and making } \\
\text { deliveries with the } \\
\text { personal car }\end{array}$ & $\begin{array}{l}\text { Both dimensions were } \\
\text { integrated, since the } \\
\text { beginning, at the same } \\
\text { time, however, } \\
\text { the focus is mostly on } \\
\text { the environmental } \\
\text { dimension. }\end{array}$ \\
\hline
\end{tabular}


Table 2. Cont.

\begin{tabular}{|c|c|c|c|c|c|c|c|}
\hline \multicolumn{8}{|c|}{ Business Development $\rightarrow$ Venture Launch } \\
\hline Cases & Start Year & Legal Form & Initial Team & Actual Team & Strategy & Resources: Intangible and Tangible & Financial Resources, Support \\
\hline $\mathrm{C} 1$ & 2010 & NGO & 2 owners & $\begin{array}{l}2 \text { owners and } \\
2 \text { employees }\end{array}$ & $\begin{array}{l}\text { To reach people who are more concerned about } \\
\text { environmental aspects and want a simpler life. } \\
\text { Also, to integrate with them through workshops } \\
\text { in the hostel }\end{array}$ & $\begin{array}{l}\text { Creativity and time available to recycle } \\
\text { resources rather than buying them in } \\
\text { the market }\end{array}$ & $\begin{array}{l}\text { They did not have any financia } \\
\text { support to start the business, } \\
\text { only received a grant to expand } \\
\text { their activities }\end{array}$ \\
\hline C2 & 2004 & NGO & $\begin{array}{l}2 \text { founders and } \\
7 \text { volunteers }\end{array}$ & $\begin{array}{l}2 \text { founders and } \\
100 \text { employees }\end{array}$ & $\begin{array}{l}\text { To make these second-hand centers look like } \\
\text { normal shops (the lights, the good smell, } \\
\text { the clothes, etc.) to attract not only poor people, } \\
\text { but also a broader population, in order to make } \\
\text { second-hand shopping a normal habit }\end{array}$ & $\begin{array}{l}\text { Knowledge, volunteers, and donator } \\
\text { that did not have any better options to } \\
\text { throw away things }\end{array}$ & $\begin{array}{l}\text { They did not have any financial } \\
\text { support to start the business }\end{array}$ \\
\hline C3 & 2016 & $\begin{array}{l}\text { Private } \\
\text { company }\end{array}$ & 4 founders & $\begin{array}{l}4 \text { owners and } \\
3 \text { employees }\end{array}$ & $\begin{array}{l}\text { The company usually calls potential clients, sets } \\
\text { up a meeting and introduces the service, } \\
\text { explaining its benefits and giving successful } \\
\text { examples. They try to show that their service is } \\
\text { not only about tracking the problem and } \\
\text { reporting it, but also providing solutions with } \\
\text { the information. }\end{array}$ & Knowledge & $\begin{array}{l}\text { Funding of initiatives to } \\
\text { support new business }\end{array}$ \\
\hline C4 & 2015 & $\begin{array}{l}\text { Private } \\
\text { company }\end{array}$ & 5 founders & $\begin{array}{l}5 \text { owners and } \\
12 \text { employees }\end{array}$ & $\begin{array}{l}\text { In the business-to-business (B2B) part, } \\
\text { the strategy was an individual approach, } \\
\text { presenting the service offered. The initial focus } \\
\text { was on small and medium businesses, } \\
\text { considered easier to accept. After the initial } \\
\text { moment, the most effective way was to show } \\
\text { just examples. To the final consumer, it was } \\
\text { through campaigns in social media and } \\
\text { conventional media, with the environmental } \\
\text { appeal and cost reduction. }\end{array}$ & $\begin{array}{l}\text { Mainly intangible resources such as } \\
\text { knowledge, dissemination of the theme } \\
\text { in the media and society, and the ability } \\
\text { to promote good experiences for } \\
\text { customers }\end{array}$ & $\begin{array}{l}\text { The business started with no } \\
\text { financial resources and working } \\
\text { in a home office. The only cost } \\
\text { was the website's maintenance. }\end{array}$ \\
\hline C5 & 1989 & $\begin{array}{l}\text { Private } \\
\text { company }\end{array}$ & $\begin{array}{c}3 \text { founders and } \\
7 \text { volunteers }\end{array}$ & $\begin{array}{c}3 \text { founders, } \\
300 \text { full-time or } \\
\text { part-time employees } \\
\text { and } 100 \text { volunteers }\end{array}$ & $\begin{array}{l}\text { Efforts to educate the population and trying to } \\
\text { make recycle and reusing things more common, } \\
\text { initially word of mouth. }\end{array}$ & Knowledge and partnerships & Yes, from the government \\
\hline
\end{tabular}


Table 2. Cont

\begin{tabular}{|c|c|c|c|c|c|c|c|}
\hline \multicolumn{8}{|c|}{ Business Development $\rightarrow$ Venture Launch } \\
\hline Cases & Start Year & Legal Form & Initial Team & Actual Team & Strategy & Resources: Intangible and Tangible & Financial Resources, Support \\
\hline $\mathrm{C} 6$ & 2001 & NGO & $\begin{array}{l}2 \text { founders and } \\
4 \text { employers } \\
\text { (full-time) }\end{array}$ & $\begin{array}{l}2 \text { founders, } \\
25 \text { full-time } \\
\text { employees and } \\
378 \text { volunteers }\end{array}$ & $\begin{array}{l}\text { First, search for partnerships with companies } \\
\text { that sought to carry out corporate social } \\
\text { responsibility actions. More recently, it has used } \\
\text { successful cases in the same industry to recruit } \\
\text { new donors, using an image linked to corporate } \\
\text { responsibility and tax deductions provided by } \\
\text { the government. }\end{array}$ & Partnerships and volunteer work & $\begin{array}{l}\text { Initially, campaigns carried out } \\
\text { in society. } \\
\text { Nowadays, campaigns carried } \\
\text { out in society, partnerships with } \\
\text { the government, partnerships } \\
\text { with the private sector, projects } \\
\text { in partnership with } \\
\text { municipalities and grants, } \\
\text { and small fees from } \\
\text { beneficiaries. }\end{array}$ \\
\hline C7 & 2009 & NGO & 3 founders & $\begin{array}{l}3 \text { founders, } 6 \text { full-time } \\
\text { employees and } \\
200 \text { volunteers }\end{array}$ & $\begin{array}{l}\text { In the beginning, collecting money donations in } \\
\text { charity, concerts, and charity campaign donation } \\
\text { boxes in stores. Nowadays, the money collection } \\
\text { is a very small part of the business and they } \\
\text { work mostly with food leftovers from the supply } \\
\text { chain and with consumers. }\end{array}$ & Partnerships and volunteer work & $\begin{array}{l}\text { Campaigns carried out in } \\
\text { society and grants. }\end{array}$ \\
\hline $\mathrm{C} 8$ & 2016 & $\begin{array}{l}\text { Private } \\
\text { company }\end{array}$ & 2 founders & $\begin{array}{l}2 \text { owners and } \\
208 \text { employees }\end{array}$ & $\begin{array}{l}\text { In the business-to-business (B2B) part, } \\
\text { the strategy was an individual approach, } \\
\text { presenting the service offered, without focusing } \\
\text { on the company size. To the final consumer, } \\
\text { it was through campaigns in social media and } \\
\text { conventional media, with environmental appeal } \\
\text { and cost reduction }\end{array}$ & $\begin{array}{l}\text { Mainly intangible resources such as } \\
\text { knowledge and dissemination of the } \\
\text { theme in the media. }\end{array}$ & $\begin{array}{l}\text { The business started with no } \\
\text { financial resources. Then they } \\
\text { received funding from angel } \\
\text { investors. }\end{array}$ \\
\hline C9 & 2015 & $\begin{array}{l}\text { Private } \\
\text { company }\end{array}$ & 2 founders & $\begin{array}{l}2 \text { owners and } \\
6 \text { employees }\end{array}$ & $\begin{array}{l}\text { It began with an individual approach in events } \\
\text { and consumer fairs related to food, being } \\
\text { disseminated after disclosure in the regular } \\
\text { media }\end{array}$ & $\begin{array}{l}\text { Partnerships and dissemination of the } \\
\text { theme in the media, as part of a social } \\
\text { movement }\end{array}$ & $\begin{array}{l}\text { The business started with no } \\
\text { financial resources. }\end{array}$ \\
\hline $\mathrm{C} 10$ & 2018 & $\begin{array}{l}\text { Private } \\
\text { company }\end{array}$ & 2 founders & $\begin{array}{l}2 \text { owners. } \\
\text { Other services are } \\
\text { outsourced }\end{array}$ & $\begin{array}{l}\text { The first clients were from an incubator test base. } \\
\text { After, the insertion in the market occurred } \\
\text { through social media posts and media reports. }\end{array}$ & $\begin{array}{l}\text { Mainly intangible resources such as } \\
\text { knowledge and dissemination of the } \\
\text { theme in the media. }\end{array}$ & $\begin{array}{l}\text { The business started with no } \\
\text { financial resources from the } \\
\text { owners, but with some financial } \\
\text { help of the incubator. }\end{array}$ \\
\hline C11 & 2012 & $\begin{array}{l}\text { Private } \\
\text { company }\end{array}$ & 1 founder & $\begin{array}{l}2 \text { owners and } \\
10 \text { employees }\end{array}$ & $\begin{array}{l}\text { The first customer was through a Facebook sales } \\
\text { page }\end{array}$ & $\begin{array}{l}\text { Mainly intangible resources such as } \\
\text { knowledge and dissemination of the } \\
\text { theme in the media. }\end{array}$ & $\begin{array}{l}\text { The business started with no } \\
\text { financial resources. }\end{array}$ \\
\hline
\end{tabular}


Table 2. Cont

\begin{tabular}{|c|c|c|c|}
\hline \multicolumn{4}{|c|}{ Business Exploitation $\rightarrow$ Impact Measurement } \\
\hline Cases & Social and Environmental Impact & Problems Facing & Future Plans \\
\hline $\mathrm{C} 1$ & $\begin{array}{l}\text { Pioneers in the city in the process of separation and final destination of different types of } \\
\text { waste. They pressed the city government to introduce more sustainable systems to deal } \\
\text { with waste. All furniture is recycled, and the sheets, towels, and blankets are second-hand, } \\
\text { bought from luxury hotels that periodically exchange their items. Offers a more affordable } \\
\text { and fairer price. Promotes educational workshops and recycling activities in the } \\
\text { community with guests on various topics related to sustainability. }\end{array}$ & $\begin{array}{l}\text { They would like to be more active in terms of promoting } \\
\text { sustainability, but the business routine requires too much } \\
\text { dedication in communicating with guests. }\end{array}$ & $\begin{array}{l}\text { To find mechanisms that enable the } \\
\text { operation with solar energy, to increase the } \\
\text { reach of the workshops, and to find } \\
\text { strategies to attract more concerned with } \\
\text { sustainability clients }\end{array}$ \\
\hline $\mathrm{C} 2$ & $\begin{array}{l}\text { In environmental terms, recycling and reusing, since the past year the company saved } \\
1500 \text { tons of textiles from the landfill. In the social aspect, a cheaper price and social charity. } \\
\text { For example, they organize a "shopping night", many times a year, for homeless people, } \\
\text { when they can choose anything from the shop for free. }\end{array}$ & $\begin{array}{l}\text { The destination of clothing leftovers that people did not } \\
\text { want, since nowadays, it is donated to a long-distance } \\
\text { organization and they understand that it is not a very } \\
\text { sustainable solution. }\end{array}$ & $\begin{array}{l}\text { To cover all the country (currently they } \\
\text { have } 11 \text { stores) in order to provide, in every } \\
\text { place, conditions for people to have the } \\
\text { opportunity of giving things away. }\end{array}$ \\
\hline $\mathrm{C} 3$ & $\begin{array}{l}\text { Environmentally, a total of } 217,920 \mathrm{~kg} \text { of food was saved from being wasted in } 2017, \\
\text { translating into over } 400,000 \text { lunch meals. It represents almost } 500,000 \text { euros in cost } \\
\text { savings. Socially, they promote a more critical perception in society about waste. } \\
\text { Some restaurants, after beginning measurements, realized that the value of wasted useful } \\
\text { food is more than twice as great as estimated. In addition, they participate in the } \\
\text { discussion about food waste with other stakeholders. }\end{array}$ & $\begin{array}{l}\text { To raise awareness of some restaurants about the } \\
\text { problem, because they often do not realize the relevance } \\
\text { of the issue }\end{array}$ & $\begin{array}{l}\text { To expand operations in the country and in } \\
\text { other Nordic countries through } \\
\text { international chains. }\end{array}$ \\
\hline $\mathrm{C} 4$ & $\begin{array}{l}\text { They save more than } 67,000 \text { portions of food from being thrown away every month, which } \\
\text { corresponds to saving } 167 \text { tons of } \mathrm{CO} 2 \text { emissions every month. Consumers are able to } \\
\text { obtain food with a } 50 \% \text { discount, which makes it affordable for people that have a low } \\
\text { income. They also carry out educational campaigns and workshops, promoting more } \\
\text { awareness of the food waste problem. }\end{array}$ & The costs of starting operations in new countries & To find a way to scale the business \\
\hline C5 & $\begin{array}{l}\text { Environmentally, promotion of reusing and recycling. Socially, in addition to education, } \\
\text { as a social enterprise, more than } 70 \% \text { of the team who train and qualify for the professional } \\
\text { market consists of people in situations of social vulnerability, such as unemployed, } \\
\text { alcoholics in treatment, and people with minor convictions. }\end{array}$ & $\begin{array}{l}\text { Training and qualification of people, in vulnerability } \\
\text { situations, are often not fit or the training time is not } \\
\text { sufficient }\end{array}$ & $\begin{array}{l}\text { To expand operations in the country and } \\
\text { other countries }\end{array}$ \\
\hline $\mathrm{C} 6$ & $\begin{array}{l}\text { Promotes efficient use of resources and public solidarity in reducing responsible } \\
\text { consumption of food. In 2017, a total of } 7456 \text { tons of food were recovered and donated. } \\
\text { The company was responsible for initiating a roundtable discussion with different } \\
\text { institutions to discuss solutions to food waste. }\end{array}$ & $\begin{array}{l}\text { To manage volunteer work, especially in recruitment and } \\
\text { long-term retention issues }\end{array}$ & $\begin{array}{l}\text { To expand operations and the network } \\
\text { capacity }\end{array}$ \\
\hline
\end{tabular}


Table 2. Cont

\begin{tabular}{|c|c|c|c|}
\hline \multicolumn{4}{|c|}{ Business Exploitation $\rightarrow$ Impact Measurement } \\
\hline Cases & Social and Environmental Impact & Problems Facing & Future Plans \\
\hline C7 & $\begin{array}{l}\text { In } 2017 \text {, they donated } 40 \text { tons of food, providing assistance to } 23,000 \text { people in total, } \\
\text { generally families with an average income of } 350 \text { euros. }\end{array}$ & $\begin{array}{l}\text { The regional partners do not have transport or enough } \\
\text { money for all operations. In addition, there is no national } \\
\text { regulation about how to deal with the waste. It affects the } \\
\text { donation of food best-before and use by date, even if it is } \\
\text { suitable for consumption. There is a lack of knowledge } \\
\text { about this issue and society does not understand the } \\
\text { difference, among other things. }\end{array}$ & $\begin{array}{l}\text { To organize conferences to put together all } \\
\text { donators and partners, from the ministry } \\
\text { and the government, to discuss new } \\
\text { solutions to food waste issues }\end{array}$ \\
\hline C8 & $\begin{array}{l}\text { They calculated that they saved } 13 \text { million meals from being wasted, which corresponded } \\
\text { to approximately a } 27 \text { million } \mathrm{CO} 2 \text { reduction. Consumers are able pay lower prices for } \\
\text { food, which makes it affordable for people that have a low income. They also carry out } \\
\text { educational campaigns and workshops, promoting more awareness of the food waste } \\
\text { problem. }\end{array}$ & $\begin{array}{l}\text { Find the best cultural approach to campaigns with } \\
\text { consumers in each country }\end{array}$ & To expand operations in other countries \\
\hline C9 & $\begin{array}{l}\text { In addition to the environmental aspect, based on sales data, the company saved } 600 \text { tons } \\
\text { of fruits and vegetables from wasting since the beginning of the operation. They help } \\
\text { producers have better living conditions in Brazil and promote several awareness } \\
\text { campaigns about food waste issues, which are disseminated to their } 1500 \text { weekly } \\
\text { customers, and to the public through the news. }\end{array}$ & $\begin{array}{l}\text { Manage the logistics of buying from small producers who } \\
\text { have small amounts of food and live in areas that are } \\
\text { more isolated. }\end{array}$ & $\begin{array}{l}\text { To better organize the management and } \\
\text { logistics structure in order to expand } \\
\text { activities }\end{array}$ \\
\hline $\mathrm{C} 10$ & $\begin{array}{l}\text { The company helped prevent more than } 5 \text { tons of food waste by educating producers that } \\
\text { there are alternative markets for these products and promoting consumer awareness. }\end{array}$ & $\begin{array}{l}\text { Some vegetables are rejected by consumers and they need } \\
\text { to make more of an effort to share recipes to prepare food } \\
\text { and remind consumers that the business proposal is to } \\
\text { accept these rejected food. }\end{array}$ & To expand operations in the city \\
\hline C11 & $\begin{array}{l}\text { The company avoids } 170 \text { tons of fruit from being wasted per month, in addition to } \\
\text { decreasing the grower's dependence on the industry, }\end{array}$ & To deal with the fruit off season & To increase the number of sales \\
\hline
\end{tabular}




\section{Discussion}

The eleven investigated cases provided important elements to analyze the different phases of the SEP. Regarding idea generation, the motivation to start the ventures, in all the analyzed cases, related to prior experience, such as education, work experience, hobbies, and founders' family background. These results align with findings and propositions in previous studies $[2,4,14,19,21,30,31]$. These situations correspond to what Yitshaki and Kropp [9] named pull factors or Mets [28] named pre-history, because they are motivationally displaced by other human and nonhuman stakeholders, causes, and ventures in different dynamic relations, corroborating the propositions in the literature [2]. Belz and Binder [6] and Perrini et al. [23] found that sensitivity towards some problems relates to entrepreneurs' motivations. In the analyzed cases, prior experience seemed to relate to this sensitivity towards a social or environmental problem.

Generally, we identified that entrepreneurs' knowledge of initiatives that propose to solve social and environmental problems was the main determinant in the process of ideation, in addition to experiences and skills in the area, as well as education or professional life. Previous experience in entrepreneurship was less relevant. Because none of the cases reported being motivated by a high need for achievement and autonomy [19], the results meet the propositions of previous studies [21,30] reporting that sustainable entrepreneurs have significant differences in their motivations as compared with their business for-profit counterparts. All the entrepreneurs were driven by goal setting [9] and considered opportunities that had sufficient potential for positive social or environmental impact to be more attractive (Guglu et al., 2002) [9,19]. In this case, their motivations were mission driven and designed to improve society's well-being [9]. The findings indicated, in many cases, that their motivations combined sustainability-oriented goals with a profit goal, as proposed by Sedlmeier, Rombach, and Bitsch [32].

Opportunity recognition, as an output of the idea development, in this study, has many characteristics deriving from the previous stage and is also affected by prior knowledge, which was proposed in other studies [21,22,30,31] and the person's life trajectory, as proposed by [21,30]. It is worth noting, in the analyzed cases, that opportunity recognition was the combination of endogenously shaped and exogenously given circumstances, according to previous propositions [16,22].

In all eleven cases, the entrepreneurs perceived market imperfections as opportunities to promote sustainable entrepreneurship [6]. They projected customer demand and possible competitive advantage [30], however, ten of eleven entrepreneurs did not test the idea, as suggested in previous investigations [9,29]. This may have an impact on meeting consumers' needs [33]. This problem, although not included in the main result of this study, was identified in the interviews, since some entrepreneurs had to make adjustments in the product or service offered, after the venture launch. This could have possibly been avoided by testing the idea before implementing it.

Opportunity development presented very homogeneous results between all cases, mainly because this phase is a continuation of the idea, the social needs, and the goals, i.e., there are no big changes throughout the entrepreneurial process. This is an interesting finding because, as proposed by Mets, Raudsaar, and Summatavet [14], the entrepreneurial process is cyclical and not linear, with feedback and readjustments. For some reason, this occurred to a lesser extent in the analyzed cases. Their business concept [6] was mostly linear. In addition, there was no business plan [12], which may be relevant in this process of feedback and readjustments. Perhaps it relates to the fact that this was the first experience of the founders with entrepreneurship. Low levels of feedback and reflection can lead to minor or relevant problems related to the businesses' success. Fortunately, in the analyzed cases, only minor adjustments were required.

Another novelty that emerged in this study relates to the translation of a social or ecological goal into customer benefits. This is a crucial element. Belz and Binder [6] discovered that the integration of the triple bottom line is a complex process, which takes place sequentially, not simultaneously. The results in this study indicate an opposite direction, since in most situations both dimensions were integrated at the same time and before venture launch. Despite this, the entrepreneur's focus was 
on only one dimension (environmental, in the nine situations in which this occurred). The social dimension occurred as an impact of the idea and the business operation and, to a lesser extent, just the opposite situation occurred, i.e., the dimensions were integrated in separate moments (first social and, then, environmental) and occurred after the venture launch. In this study, the entrepreneur's focus is on only one of the dimensions (social, in these two cases) and the environmental dimension occurs as an impact of the business.

Venture launch involves the final practical aspects and the effective entry of the business into the market. It is the moment when the sustainable product or service is commercialized in the market [6]. The cases analyzed did not use the possibilities of financial resources proposed by Karhunen et al. [29] or by Belz and Binder [6]. Fewer cases used the possibilities listed by Shaw and Carter [19], while the majority kept their costs to a minimum. Regarding the legal form, organizations characterized themselves as private ownership logic [12] when they found a niche market [6], or charitable organizations [19] that relied on private money or donations or public grants [34]. Regarding scalability, the empirical findings are similar to other propositions of Perrini et al. [23], since they seek the scalability of their organizational model in order to increase the impact and induce social and environmental change.

Finally, sustainable impact measurement emerges as a new category based on the premise that the creation of a positive social and environmental impact (according to the classification) is considered a necessary condition for social or sustainable entrepreneurship $[2,4,7,8,11,12,18,35]$. If this is a necessary condition for sustainable entrepreneurship and it is, in practice, different from regular entrepreneurship, the SEP does not end with the venture launch. The process of the sustainable entrepreneurship ends when it produces the effective positive economic, environmental, and social impact on society. Finally, Kornish and Ulrich [26] proposed that the quality of the original conception of an idea (raw idea) is a key determinant of entrepreneurial success. In all of the cases analyzed in this study, this proposition was verified, since the original idea was implemented and exploited with minor adjustments until the last phase (impact measurement).

Therefore, based on the findings of this study and the discussion, the following flow for sustainable entrepreneurship is proposed in Figure 1, independent of the theoretical model, which analyzes the processes that lead to these outputs.

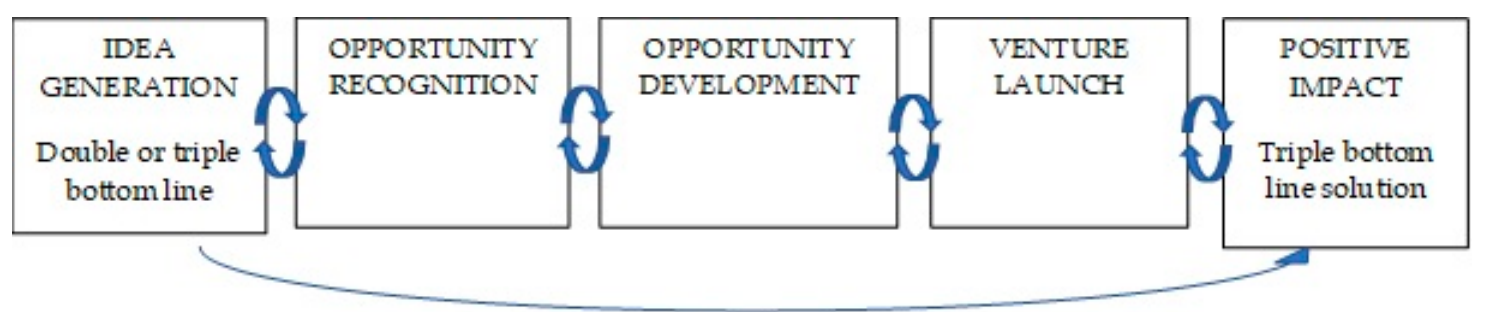

Figure 1. Sustainable entrepreneurial process flow.

The proposition made in Figure 1, regardless of which model of the phases related to the SEP process, is that the flow with the outputs, in the case of sustainable entrepreneurship, ends only when it produces a positive impact. This is necessary, first, to differentiate the SEP from the regular entrepreneurial process, since the literature already recognizes impact production as a necessary step for this type of business.

Secondly, according to the analyzed cases, the three dimensions do not always integrate before the venture launch, as proposed by Belz and Binder [6]. In the cases analyzed, there are two different situations, both generating impacts in the three dimensions of sustainability. The first situation is when the three dimensions already appear in the idea generation, even if the main objective is to focus only on the social or environmental aspect, and they are reflected in the positive impacts produced in society. The second situation is when only one of these dimensions appears until the venture launch phase. By adaptations in the offered product or services, after the venture launch, the third 
dimension integrates. This also produces a positive impact on the three dimensions of sustainability. Both situations, by prior definition, characterize the sustainable entrepreneur, and therefore reinforce the importance of including the impact measurement in the SEP. If it were evaluated in the venture launch phase, this process, although characterized as a sustainable entrepreneurship in the real situation, would not be classified in the literature as such.

Social entrepreneurship can also apply to this same reasoning. There are many discussions about the definition of social entrepreneurship. The social impact assessment in these cases, regardless of this dimension being present in the initial phase of the entrepreneurial process, would provide a more accurate and factual classification. Finally, the quality of the initial idea is extremely relevant to the impacts produced by these entrepreneurs, since little changes throughout the SEP, in the analyzed cases.

On the basis of empirical evidence and the results found, probably the most important lesson is that in order to achieve the United Nations Sustainable Development Goals, interested stakeholders must go beyond the search for the best practices to promote sustainable entrepreneurship. We conclude that it is more relevant to work together with these three actions through the collaboration of multi-stakeholder with the aim to converge them. Therefore, individuals experience, in a more practical way, problems in the environmental and social dimensions of sustainability, which encourages discussions and reflection processes, as well as disseminates innovative business solutions that are successful in similar or different contexts.

Therefore, universities, government entities, and other stakeholders interested in sustainable development could make efforts to develop the abovementioned mechanisms. These mechanisms can promote the following: (a) Educational experiences in the sustainability area more aligned with the problems of local communities; (b) stronger dissemination of successful business cases related to sustainability in other countries and contexts; and (c) more integration between universities and businesses, so that not only students could be impacted, but also people in these businesses could have access to new solutions and ideas. One possibility is through project-based learning or practice-based learning, which also includes reflection processes. Perhaps these mechanisms can give individuals the necessary experience and enable them to better recognize entrepreneurial solutions to social or environmental problems that they may come across in their trajectories.

Entrepreneurs are facing opportunities to develop win-win business models through sustainable entrepreneurship. They need to be aware of problems in their communities, visit places and different stakeholders, and talk to people. When identifying problems, first, it is interesting to check whether solutions to similar problems have been developed elsewhere and to try to adapt to the local context, before trying to develop something new. The results identified that no significant financial resources are required to promote venture launch. More robust investments are only required for expansion if the developed solution has the potential to scale in the market. In this sense, scalability is a word that needs to be in the minds of entrepreneurs when developing sustainable solutions.

Moreover, as part of their operating strategy, businesses need to promote consumer awareness through many educational campaigns, preferably disseminating intangible values and offering more convenience and better prices to consumers.

In this sense, supporting startups and new ventures through public policies is essential to generate social change. Government leaders should define which United Nations Sustainable Development Goals are most relevant in a given context and offer incentives for new businesses in these priority areas. It is also important to develop monitoring and measuring tools to assess and promote more effective public policy. These priority areas and measuring tools need to be debated and decided upon in multi-stakeholder meetings to consider their feasibility. In addition, national objectives must be continuously communicated in relation to what actions need to be developed in the short, medium, and long term. 


\section{Conclusions}

The objective of this paper was to investigate how entrepreneurs generate ideas, as well as recognize, develop, and exploit opportunities in the context of sustainable development. The findings address a series of mechanisms that occur prior to the process of generating an idea and are relevant to the positive impact of these businesses on society. On the basis of the empirical evidences, entrepreneurs' previous experiences and skills in the area, as well as their knowledge of similar initiatives that propose to solve social or environmental problems, strongly relates to their motivation and idea generation. In addition, the quality of the initial idea is extremely relevant to the impacts produced by these entrepreneurs, since apparently little changes occur throughout the process. These mechanisms led to the recognition of triggers that can stimulate the SEP.

By creating a more wholesome picture of SEP, we have contributed to the literature, filling the gap identified by Belz and Binder [6] and Hanohov and Baldacchino [21] about knowledge in the field of sustainable entrepreneurship, as well as the gap pointed out by Filser et al. [24] related to the need for research addressing how entrepreneurial activities contribute to the achievement of the United Nations Sustainable Development Goals.

Especially, this investigation provided a systemic perspective on SEP and identified that impact measurement is a necessary phase to be included into SEP models, since it differentiates this type of entrepreneurship from others. It also enables incorporation of cases that integrate the third dimension of sustainability after venture launch. This study also responded to a need, pointed out by the literature $[3,10,12,13,15,16,18,22]$, for more investigations in different phases of the entrepreneurial process. In the practical field, this study contributes by presenting empirical evidence of the phenomenon of sustainable entrepreneurship, which is considered rare according to Renko [13]. The holistic knowledge of the sustainable entrepreneurial process provides new information that supports academics, policy makers, government, and individuals, with a more appropriate understanding of the conditions that help to stimulate new business activities dealing with economic, social, and environmental problems faced in society.

Despite exploring a relevant number of cases, in six different countries, with organizations from different sectors, including not-for-profit and for-profit, as well as different legal forms, this study has some limitations. One limitation relates to the fact that, as an exploratory investigation, findings cannot be extrapolated to broader populations. To improve generalization, it would also be beneficial for future studies to broaden the sample and pursue comparative research between industries, countries, and regions, as well as promote quantitative studies. A second limitation of this study is that the learning process was not evaluated considering space constraint. Future studies may also focus on this relevant aspect. As proposed by Reis [40], qualitative case studies can be limited by the sensitivity of the investigators. Moreover, cases two and five, cases six and seven, and cases nine and 10 presented the same products or services. The fact that they presented a similar pattern of results in the data analysis helps to corroborate the findings of this research, but also represents a possible limitation of the qualitative analysis to could be improved through future research that aims to diversify the type of units of analysis.

Future studies could also examine the best ways to align educational experiences with the problems of local communities, possibilities to promote better impact on the dissemination of successful business cases, and alternatives to increase integration between universities and businesses to stimulate SEP in entrepreneurs and students.

Author Contributions: D.E.M. elaborated the literature review, collected data, and performed the first data analyses; M.R., T.M., and M.D.d.B. made the supervision, data validation, and review. T.M. conducted the funding acquisition.

Funding: This research was funded by the Coibra Group and CAPES, Finance Code 001.

Conflicts of Interest: The authors declare no conflict of interest. 


\section{References}

1. Govindan, K. Sustainable consumption and production in the food supply chain: A conceptual framework. Int. J. Prod. Econ. 2018, 195, 419-431. [CrossRef]

2. Fors, P.; Lennerfors, T.T. The individual-care nexus: A theory of entrepreneurial care for sustainable entrepreneurship. Sustainability 2019, 11, 4904. [CrossRef]

3. Gregori, P.; Wdowiak, M.A.; Schwarz, E.J.; Holzmann, P. Exploring value creation in sustainable entrepreneurship: Insights from the institutional logics perspective and the business model lens. Sustainability 2019, 11, 2505. [CrossRef]

4. Jiao, H. A conceptual model for social entrepreneurship directed toward social impact on society. Soc. Enterp. J. 2011, 7, 130-149. [CrossRef]

5. Seelos, C.; Mair, J.; Battilana, J.; Dacin, M.T. The embeddedness of social entrepreneurship: Understanding variation across local communities. In Communities Organ; Emerald Group Publishing Limited: Bingley, UK, 2011; pp. 333-363.

6. Belz, F.M.; Binder, J.K. Sustainable entrepreneurship: A convergent process model. Bus. Strategy Environ. 2017, 26, 1-17. [CrossRef]

7. Cohen, B.; Smith, B.; Mitchell, R. Toward a sustainable conceptualization of dependent variables in entrepreneurship research. Bus. Strategy Environ. 2008, 17, 107-119. [CrossRef]

8. Kuratko, D.F. Entrepreneurship: Theory, Process, and Practice; Cengage Learning: Boston, MA, USA, 2016.

9. Yitshaki, R.; Kropp, F. Motivations and opportunity recognition of social entrepreneurs. J. Small Bus. Manag. 2016, 54, 546-565. [CrossRef]

10. Drencheva, A.; Folmer, E.C.; Renko, M.; Tunezerwe, S.; Williams, T.A. Social change and social ventures: Emerging developments in social entrepreneurship. In Academy of Management Proceedings; Academy of Management: Briarcliff Manor, NY, USA, 2018; Volume 2018, p. 1156.

11. Gordon, K.; Wilson, J.; Tonner, A.; Shaw, E. How can social enterprises impact health and well-being? Int. J. Entrep. Behav. Res. 2018, 24,697-713. [CrossRef]

12. Margiono, A.; Zolin, R.; Chang, A. A typology of social venture business model configurations. Int. J. Entrep. Behav. Res. 2018, 24, 626-650. [CrossRef]

13. Renko, M. Early challenges of nascent social entrepreneurs. Entrep. Theory Pract. 2013, 37, $1045-1069$. [CrossRef]

14. Mets, T.; Raudsaar, M.; Summatavet, K. Experimenting social constructivist approach in entrepreneurial process-based training: Cases in social, creative and technology entrepreneurship. In The Experimental Nature of New Venture Creation; Springer: Cham, Switzerland, 2013; pp. 107-125.

15. Dimov, D. Grappling with the unbearable elusiveness of entrepreneurial opportunities. Entrep. Theory Pract. 2011, 35, 57-81. [CrossRef]

16. Vogel, P. From venture idea to venture opportunity. Entrep. Theory Pract. 2017, 41, 943-971. [CrossRef]

17. González, M.F.; Husted, B.W.; Aigner, D.J. Opportunity discovery and creation in social entrepreneurship: An exploratory study in Mexico. J. Bus. Res. 2017, 81, 212-220. [CrossRef]

18. Choi, N.; Majumdar, S. Social entrepreneurship as an essentially contested concept: Opening a new avenue for systematic future research. J. Bus. Ventur. 2014, 29, 363-376. [CrossRef]

19. Shaw, E.; Carter, S. Social entrepreneurship: Theoretical antecedents and empirical analysis of entrepreneurial processes and outcomes. J. Small Bus. Enterp. Dev. 2007, 14, 418-434. [CrossRef]

20. Siqueira, A.C.O.; Guenster, N.; Vanacker, T.; Crucke, S. A longitudinal comparison of capital structure between young for-profit social and commercial enterprises. J. Bus. Ventur. 2018, 33, 225-240. [CrossRef]

21. Hanohov, R.; Baldacchino, L. Opportunity recognition in sustainable entrepreneurship: An exploratory study. Int. J. Entrep. Behav. Res. 2018, 24, 333-358. [CrossRef]

22. George, N.M.; Parida, V.; Lahti, T.; Wincent, J. A systematic literature review of entrepreneurial opportunity recognition: Insights on influencing factors. Int. Entrep. Manag. J. 2016, 12, 309-350. [CrossRef]

23. Perrini, F.; Vurro, C.; Costanzo, L.A. A process-based view of social entrepreneurship: From opportunity identification to scaling-up social change in the case of San Patrignano. Entrep. Reg. Dev. 2010, 22, 515-534. [CrossRef]

24. Filser, M.; Kraus, S.; Roig-Tierno, N.; Kailer, N.; Fischer, U. Entrepreneurship as catalyst for sustainable development: Opening the black box. Sustainability 2019, 11, 4503. [CrossRef] 
25. Davidsson, P. Researching Entrepreneurship; Springer: New York, NY, USA, 2005.

26. Kornish, L.J.; Ulrich, K.T. The importance of the raw idea in innovation: Testing the sow's ear hypothesis. J. Mark. Res. 2014, 51, 14-26. [CrossRef]

27. Vuorio, A.M.; Puumalainen, K.; Fellnhofer, K. Drivers of entrepreneurial intentions in sustainable entrepreneurship. Int. J. Entrep. Behav. Res. 2018, 24, 359-381. [CrossRef]

28. Mets, T. Creative business model innovation for globalizing SMEs. In Entrepreneurship-Creativity and Innovative Business Models; IntechOpen: London, UK, 2012.

29. Foley, J.A.; Ramankutty, N.; Brauman, K.A.; Cassidy, E.S.; Gerber, J.S.; Johnston, M.; Balzer, C. Solutions for a cultivated planet. Nature 2011, 478, 337-342. [CrossRef] [PubMed]

30. Karhunen, P.; Arvola, K.; Küttim, M.; Venesaar, U.; Mets, T.; Raudsaar, M.; Uba, L. Creative Entrepreneurs' Perceptions about Entrepreneurial Education; Paper Report; University of Tartu: Tartu, Estonia, 2011.

31. Shane, S. Prior knowledge and the discovery of entrepreneurial opportunities. Organ. Sci. 2000, 11, 448-469. [CrossRef]

32. Sedlmeier, R.; Rombach, M.; Bitsch, V. Making food rescue your business: Case studies in Germany. Sustainability 2019, 11, 5101. [CrossRef]

33. Guclu, A.; Dees, J.G.; Anderson, B.B. The process of social entrepreneurship: Creating opportunities worthy of serious pursuit. Cent. Adv. Soc. Entrep. 2002, 1, 1-15.

34. Doherty, B.; Haugh, H.; Lyon, F. Social enterprises as hybrid organizations: A review and research agenda. Int. J. Manag. Rev. 2014, 16, 417-436. [CrossRef]

35. Shin, C.; Park, J. How social entrepreneurs' value orientation affects the performance of social enterprises in Korea: The mediating effect of social entrepreneurship. Sustainability 2019, 11, 5341. [CrossRef]

36. Costa, E.; Pesci, C. Social impact measurement: Why do stakeholders matter? Sustain. Account. Manag. Policy J. 2016, 7, 99-124. [CrossRef]

37. Dorado, S.; Ventresca, M.J. Crescive entrepreneurship in complex social problems: Institutional conditions for entrepreneurial engagement. J. Bus. Ventur. 2013, 28, 69-82. [CrossRef]

38. Yin, R.K. Case Study Research and Applications: Design and Methods; Sage publications: Thousand Oaks, CA, USA, 2017.

39. Organisation for Economic Cooperation and Development (OECD). Social Expenditure Database (SOCX); January 2019: Social Expenditure Update; OECD: Paris, France, 2019; Available online: https://www.oecd. org/social/expenditure.htm (accessed on 22 October 2019).

40. Reis, R. Strengths and Limitations of Case Studies; Stanford University: Stanford, CA, USA, 2009. 